\title{
A multilocus allozyme discontinuity in the mussel Mytilus galloprovincialis: the interaction of ecological and life-history factors
}

\author{
Humberto Quesada, Carlos Zapata, Gonzalo Alvarez \\ Departamento de Bioloxia Fundamental, Area de Xenetica, Universidade de Santiago de Compostela, \\ E-15706 Santiago de Compostela, Spain
}

\begin{abstract}
Electrophoretically detectable genetic variability of the Mediterranean mussel Mytilus galloprovincialis Lmk, was examined at 15 allozyme loci in 21 populations ranging from Santander (northern Spain) to Livorno (northwestern Italy). A major genetic break between Almeria and Alicante (southeastern Spain), as evidenced by 11 of 13 polymorphic loci examined, delimits 2 groups of populations with a high internal homogeneity. Roughly $75 \%$ of the total genetic differentiation was attributable to the divergence between these 2 groups of populations that displayed a genetic distance between them $(\mathrm{D}=0.03$ ) in the range of conspecific populations. This genetic break in M. galloprovincialis contrasts with earlier reports of genetic homogeneity among conspecific populations of the genus Mytilus over vast geographical distances, and represents an uncommon result in marine organisms with larval dispersal. The zone of genetic divergence in $M$. galloprovincialis corresponds to a discontinuity in the distribution of this mussel, and to the position of the well-defined Almeria-Oran oceanographic front, with a distributional boundary between Atlantic and Mediterranean communities. In this region, other marine species exhibit similar patterns of intraspecific divergence, suggesting the action of common biogeographic processes. It is proposed that contemporary influences on gene flow related to an ecological barrier, perhaps in combination with selective pressures associated to water mass differences, maintain the abrupt change in southeastern Spain.
\end{abstract}

KEY WORDS: Mytilus · Allozyme · Genetic discontinuity · Larval dispersal · Ecological barrier

\section{INTRODUCTION}

Studies on protein variation have revealed that a great variety of terrestrial species are divided into a mosaic of genetically distinct populations, separated by narrow zones of hybridization (Barton \& Hewitt $1985,1989)$. Such zones have been interpreted as the result of selection maintaining steep intraspecific clines in contiguous populations or, more frequently, as the result of secondary (post-glacial) contact and hybridization between previously isolated populations (Endler 1977, Barton \& Hewitt 1985, Hewitt 1989). In marine invertebrates, reports of zones of contact among genetically distinct populations are rare. Most of these reports involve hybridization between closely related species (Schopf \& Murphy 1973, Pesch 1974, Solignac 1976, Skibinski et al. 1978, 1983, Bert \& Harri- son 1988, Väinölä \& Hvilson 1991, Sarver \& Foltz 1993), and examples of transition zones at the intraspecific level are uncommon (Marcus 1977, Bulnheim \& Scholl 1981, Väinölä \& Varvio 1989, Avise 1992). Because most marine organisms have planktonic dispersal, the potential for high gene flow is thought to generally swamp the effects of forces acting to maintain genetic differentiation, except where historical geo- or ecophysical barriers have separated gene pools for periods of time (Johnson 1974, Tracey et al. 1975, Marcus 1977 . Love \& Larson 1978, Winans 1980, Davis et al. 1981, Beaumont 1982, Burton \& Feldman 1982, Mork et al. 1985, Mitton et al. 1989, Väinölä \& Varvio 1989, Macaranas et al. 1992, Planes 1993, Ayvazian et al. 1994). However, a larval pelagic strategy does not ensure geographically extensive homogeneity, since macro- and microgeographic clines have been com- 
monly reported. Nevertheless, most of these reports involve 1 or a few loci (e.g. Schopf \& Gooch 1971, Williams et al. 1973, Christiansen \& Frydenberg 1974, Johnson 1974, Koehn et al. 1976, Marcus 1977, Levinton \& Suchanek 1978, Fujio 1979, Sassaman \& Yoshiyama 1979, Bulnheim \& Scholl 1981, Buroker 1983, Koehn \& Hilbish 1987, Saavedra et al. 1993), and examples of clinal variation for a large number of genes are rare (Väinölä \& Varvio 1989, Ropson et al. 1990). While it has long been appreciated that natural selection may be responsible for this differentiation, the fact that dispersal capacities may not reflect levels of gene flow due to the action of extrinsic factors has received comparatively less consideration (Burton 1983, Hedgecock 1986, Bertness \& Gaines 1993). At present, an important issue in evolutionary biology concerns whether general and predictable relationships exist between these extrinsic forces and the phylogeographic structures of species with larval dispersal.

The genus Mytilus is an excellent model for such studies, since much is known about its genetics, physiology and ecology (reviewed in Gosling 1992a), thus allowing a multidisciplinary approach in investigating the specific mechanisms operating to effect differentiation and adaptation events in species with long larval dispersal capabilities. Interestingly, the range of $M$. galloprovincialis in Europe extends throughout very different biogeographic provinces, from the Black Sea and Mediterranean to the Atlantic coast of France and the British Isles, as far as north as the Shetland and Orkney Islands (Koehn 1991, Gardner 1992, Gosling 1992c, Seed 1992). However, the analysis of macrogeographic variation in natural populations of $M$. galloprovincialis has received comparatively much less attention than in other Mytilus taxa (reviewed in Quesada 1992).

Here we present the results of an extensive survey on allozyme variation (15 loci, 21 samples, 2300 individuals) of natural populations of Mytilus galloprovincialis from southern Europe, the only region of the continent where this type of mussel is not intermixed with other Mytilus taxa (Koehn 1991, Gosling 1992b, Quesada 1992). The sample area covered a distance of approximately $4000 \mathrm{~km}$, and samples were more densely distributed than in earlier studies of geographic variation on $M$. galloprovincialis. A major and unexpected multilocus genetic break distinguishing 2 groups of populations and associated with a welldefined biogeographic border are documented, and possible explanations for this result are examined. The results of this study suggest a new empirical appraisal of the influences of patterns of water currents, habitat and life history on the magnitude and pattern of genetic differentiation in marine species with high dispersal capabilities.

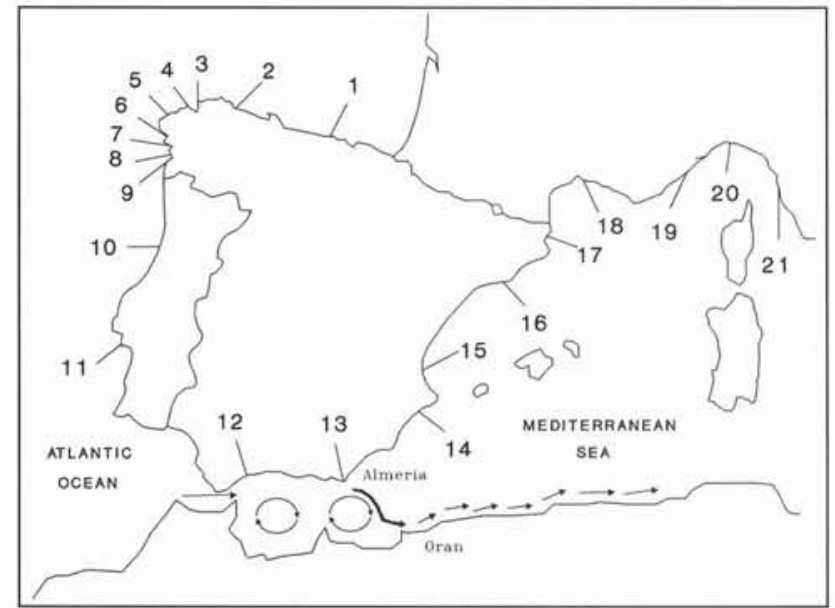

Fig. 1. Location of sampling sites along the southwest coasts of Europe and typical marine surface currents south of Spain (after Tintore et al. 1988). Mytilus galloprovincialis samples were collected from: (1) Santander, (2) Ribadeo, (3) Malata, (4) Sada, (5) Laxe, (6) Portosin, (7) Carril, (8) Rande, (9) Silleiro, (10) Aveiro, (11) Sesimbra, (12) Marbella, (13) Almeria, (14) Alicante, (15) Cullera, (16) Garraf, (17) LLansa, (18)

Palavas, (19) Montecarlo, (20) Genova, (21) Livorno

\section{MATERIALS AND METHODS}

Sampling. Natural populations of adult mussels were collected from 21 sites during 1988 to 1990 along the southwest coasts of Europe, from Santander (northern Spain) to Livorno (northwestern Italy) (Fig. 1, Table 1). Specimens were sampled in the intertidal zone, except in Almeria and Alicante, where they were collected by divers from depths of 4 and $8 \mathrm{~m}$ respectively. Mussels were transported on ice to the laboratory, where they were dissected and stored at $-70^{\circ} \mathrm{C}$ for up to 8 mo until analyzed by electrophoresis. No qualitative differences in allelic typing were found between fresh and frozen tissues.

Table 1. Sampling dates of Mytilus galloprovincialis populations. Population numbers are as in Fig. 1

\begin{tabular}{|c|c|c|c|}
\hline Population & $\begin{array}{l}\text { Sampling } \\
\text { date }\end{array}$ & Population & $\begin{array}{c}\text { Sampling } \\
\text { date }\end{array}$ \\
\hline 1. Santander & Jul 1989 & 12. Marbella & Oct 1988 \\
\hline 2. Ribadeo & Jun 1988 & 13. Almeria & Feb 1990 \\
\hline 3. Malata & May 1988 & 14. Alicante & Feb 1990 \\
\hline 4. Sada & Jan 1988 & 15. Cullera & Feb 1990 \\
\hline 5. Laxe & Jan 1988 & 16. Garraf & Aug 1988 \\
\hline 6. Portosin & Jul 1988 & 17. LLansa & Sep 1988 \\
\hline 7. Carril & Jan 1988 & 18. Palavas & Sep 1988 \\
\hline 8. Rande & Jan 1988 & 19. Montecarlo & Sep 1988 \\
\hline 9. Silleiro & Mar 1988 & 20. Genova & Jul 1989 \\
\hline 10. Aveiro & Sep 1988 & 21. Livorno & Jul 1989 \\
\hline 11. Sesimbra & Sep 1988 & & \\
\hline
\end{tabular}


Protein electrophoresis. Soluble proteins were extracted by homogenizing individual tissues with an equal volume of $0.01 \mathrm{M}$ dithiothreitol solution, and centrifuging this mixture at $7000 \times g$ for $5 \mathrm{~min}$. The supernatant was absorbed onto filter-paper wicks, which were placed into a slit cut in horizontal gels cooled to $4^{\circ} \mathrm{C}$. We used the following buffer-isozyme combinations with digestive gland $(\mathrm{G})$ or posterior adductor muscle (A) to resolve gene products of 15 presumptive loci, which include most of those reported to date in the genus Mytilus. A tris-citrate buffer, $\mathrm{pH}$ 7.0 (Ahmad et al. 1977) resolved isozymes of aspartate aminotransferase (AAT-1, AAT-2 [D], E.C. 2.6.1.1), aminopeptidase (AP [D], E.C. 3.4.-.), isocitrate dehydrogensase $(I D H[A]$, E.C. 1.1.1.42), leucine aminopeptidase-2 (LAP-2 [D], E.C. 3.4.11.-) and 6-phosphogluconate dehydrogenase (6PGDH [A], E.C. 1.1.1.43). A sodium acetate buffer, pH 5.6 (Ahmad et al. 1977) resolved the products of esterase-D (EST-D [D], E.C. 3.1.1.1) and leucine aminopeptidase-1 (LAP-1 [D], E.C. 3.4.11.-). A discontinuous tris-citrate, litium-borate, pH 8.5 (Grant \& Cherry 1985) resolved diaphorase $(D I A$ [D], E.C. 1.8.1.4), octopine dehydrogenase $(O D H$ [D], E.C. 1.5.1.11) and superoxide dismutase (SOD [D], E.C. 1.15.1.1). A tris-maleic EDTA buffer, pH 7.4 (Shaw \& Prasad 1970) was used for mannose phosphate isomerase (MPI $[\mathrm{A}], 5.3 .1 .8)$ and phosphoglucomutase $(P G M[A]$, E.C. 5.4.2.2). A tris-borate-EDTA buffer, pH 8.0 (Ahmad et al. 1977) and pH 8.7 (Dando et al. 1981), resolved phosphoglucose isomerase (PGI [A], E.C. 5.3.1.9) and strombine dehydrogenase (STDH [A], E.C. 1.5.1.-) respectively. A total of 10 samples were characterized for all 15 loci, 6 samples were scored for 14 loci (DIA not assayed), and the remaining 5 samples were examined for a variable set of loci (12 to 14) (see Appendix).

Enzyme systems were resolved on 10 to $12 \%$ starch gels, except $P G I$, which was resolved on $6 \%$ polyacrylamide gels. The staining recipes for $O D H$ and $S T D H$ were essentially those described by Dando et al. (1981) and Grant \& Cherry (1985) respectively. For DIA the method given by Harris \& Hopkinson (1976) was used. For all other systems the staining schemes were derived from Shaw \& Prasad (1970). Subunit structures of enzymes inferred from the patterns of banding on gels were in agreement with those previously reported in the genus Mytilus, based on breeding data (Hvilson \& Theisen 1984) and comparisons with related taxa (Fujio et al. 1983). Loci and alleles were labelled 1, 2, 3 , etc., beginning with the less-anodally migrating bands. Two mussels were rerun in each gel to ensure the accuracy of relative electromorph mobilities between different samples and gels.

Data analysis. Heterogeneity among populations was tested using the Pearson chi-squared contingency test for allelic frequencies. For this analysis, classes with expected frequencies less than 5 were grouped (Haberman 1988).

Patterns of geographical variation were examined graphically at each locus by plotting allelic frequencies against geographical distances. To facilitate the visualization and comparison of the variation between alleles at very different frequencies, allelic frequencies were converted to standardized deviates (deviation from the mean allelic frequency in the whole data set expressed in standard deviation units). Clinal variation was tested by Pearson correlation coefficient of arcsinetransformed allele frequencies with geographical distances (Sokal \& Rohlf 1981).

The relative amount of genetic variation among populations for individual loci and the whole data set of loci was assessed using hierarchical gene diversity coefficients (Nei 1973, 1987, Chakraborty 1980). The genetic differentiation was also examined by the unbiased estimates of genetic distances (Nei 1972), and the resultant matrix of pairwise standard genetic-distance values was used to generate UPGMA phenograms (Sneath \& Sokal 1973). The overall gene flow was calculated from the estimated level of subdivision via the relation (Slatkin \& Barton 1989): $\mathrm{G}_{\mathrm{ST}}=1 /(1+4 \mathrm{Nm})$, where $\mathrm{Nm}$ is the average number of migrant individuals per generation. This method has been proposed as the most reliable indirect estimator of gene flow (Slatkin \& Barton 1989).

Genotypic frequencies at each locus were assessed for goodness-of-fit to Hardy-Weinberg proportions by means of the unbiased $f$-statistic developed by Robertson \& Hill (1984). The significance of $f$ was evaluated using the test given by the ratio of the estimate to its standard error, which is more powerful than the traditional chi-squared test (Robertson \& Hill 1984). We also tested for non-random assortment of genotypes at 2 loci by the Pearson chi-squared contingency test. For this analysis, only the most frequent alleles were considered in each calculation.

Most of the genetic parameters were calculated using the BIOSYS- 1 computer program modified for an IBM-PC (Swofford \& Selander 1981). Robertson \& Hill's (1984) $f$-statistics were computed using the GENET-2 program (Quesada et al. 1992). The remaining statistical tests were carried out using the SPSS/PC package program (Nei et al. 1970). Tests were adjusted using the sequential Bonferroni method when many tests were performed simultaneously (Rice 1989).

\section{RESULTS}

Allele frequencies and sample sizes for each locus and site are presented in the Appendix. Out of a total 


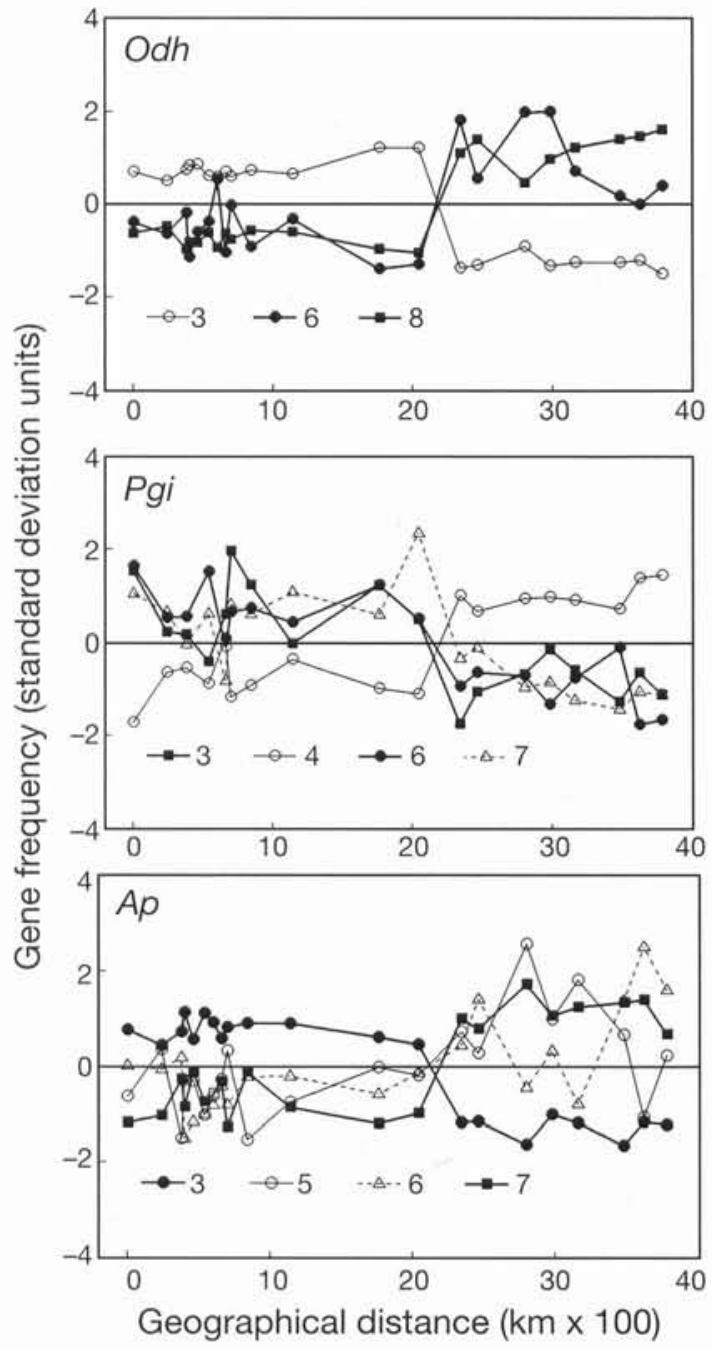

Fig. 2. Mytilus galloprovincialis. Geographic variation in allele frequencies at loci Odh, Pgi and Ap. Only the most frequent allele at each locus and alleles with significant geographical heterogeneity are plotted of 15 loci, 2 (Sod and Aat-2) were monomorphic at the $95 \%$ level in all sites examined. The remaining 13 loci showed consistent polymorphism in the sample locations along the southwestern coasts of Europe. Mean heterozygosity over 15 loci ranged from $0.360 \pm 0.069$ (Santander) to $0.334 \pm 0.068$ (Livorno). The average number of alleles per locus was between $4.93 \pm 0.58$ (Almeria) and $4.13 \pm 0.46$ (Alicante).

Inspection of the allelic variation presented in this study reveals significant shifts in allelic frequencies between the samples collected between Santander and Almeria (area 1 ; sites 1 to 13) and those taken between Alicante and Livorno (area 2; sites 14 to 21), with differences between these 2 regions generally greater than those within either area (Table 2, Figs. 2 to 4). It must be noted, however, that the number of loci and alleles with significant geographical heterogeneity might be inflated. This effect is a consequence of the increase in type I error resulting from multiple significance test of the same null hypothesis (Miller 1981), as well as the non-independence of the tests performed for the alleles segregating within each locus. These problems may be avoided by using the sequential Bonferroni correction. This method controls the type I error by means of a tablewide significance level, and it does not require the independence of the singlesignificance tests (Holm 1979, Rice 1989). After carrying out this adjustment, both significant differences were found in the total region (12 loci) and in area 1 (3 loci), but no locus significant heterogeneity was observed in area 2 (Table 2). After the Bonferroni adjustment, correlation analysis of allele frequencies with geographical distance did not reveal significant clinal variation at any locus within populations from area 1 or area 2 (results not shown).

Regarding the pattern and magnitude of the geographical variation, the loci analyzed may be classified

Table 2. Mytilus galloprovincialis. Mean allele frequencies and significance levels for heterogeneity $\chi^{2}\left[\mathrm{p}\left(\chi^{2}\right)\right]$ in samples from area 1 (sites 1 to 13), area 2 (sites 14 to 21) and the total (sites 1 to 21). Significant tests after sequential Bonferroni correction are underlined (tablewide significant level $=0.05$ ). Loci with a total significant heterogenity also showed significant differences in mean allele frequencies between areas 1 and 2 (arcsine $t$-testing). Alleles with an average frequency across all populations lower than 0.01 were not tested for heterogeneity. ns: non significant

\begin{tabular}{|c|c|c|c|c|c|c|c|c|}
\hline \multirow{2}{*}{$\begin{array}{l}\text { Locus } \\
\text { Allele }\end{array}$} & \multicolumn{3}{|c|}{ Area 1} & \multicolumn{3}{|c|}{ Area 2} & \multicolumn{2}{|c|}{ Total } \\
\hline & Mean \pm SE & $p\left(\chi^{2}\right)$ & $\mathrm{p}\left(\chi^{2}\right)$ & Mean $\pm \mathrm{SE}$ & $\mathrm{p}\left(\chi^{2}\right)$ & $\mathrm{p}\left(\chi^{2}\right)$ & $\mathrm{p}\left(\chi^{2}\right)$ & $\mathrm{p}\left(\chi^{2}\right)$ \\
\hline Aat-1 & & & ns & & & ns & & $\underline{0.0087}$ \\
\hline Aat- $1^{2}$ & $0.932 \pm 0.006$ & ns & & $0.905 \pm 0.007$ & ns & & 0.0306 & \\
\hline Aat $-1^{4}$ & $0.043 \pm 0.005$ & ns & & $0.041 \pm 0.004$ & ns & & ns & \\
\hline Aat $-1^{6}$ & $0.011 \pm 0.002$ & ns & & $0.046 \pm 0.005$ & ns & & $\underline{0.0000}$ & \\
\hline Ap & & & ns & & & ns & & $\underline{0.0000}$ \\
\hline$A p^{3}$ & $0.410 \pm 0.007$ & ns & & $0.163 \pm 0.010$ & ns & & $\underline{0.0000}$ & \\
\hline$A p^{5}$ & $0.351 \pm 0.008$ & ns & & $0.419 \pm 0.019$ & ns & & $\overline{0.0090}$ & \\
\hline$A p^{6}$ & $0.174 \pm 0.006$ & ns & & $0.238 \pm 0.017$ & 0.0111 & & 0.0000 & \\
\hline$A p^{7}$ & $0.048 \pm 0.006$ & 0.0028 & & $0.157 \pm 0.007$ & ns & & 0.0000 & \\
\hline
\end{tabular}


Table 2 (continued)

\begin{tabular}{|c|c|c|c|c|c|c|c|c|}
\hline \multirow{2}{*}{$\begin{array}{l}\text { Locus } \\
\quad \text { Allele }\end{array}$} & \multicolumn{3}{|c|}{ Area 1} & \multicolumn{3}{|c|}{ Area 2} & \multicolumn{2}{|c|}{ Total } \\
\hline & Mean $\pm \mathrm{SE}$ & $p\left(\chi^{2}\right)$ & $p\left(\chi^{2}\right)$ & Mean $\pm \mathrm{SE}$ & $p\left(\chi^{2}\right)$ & $\mathrm{p}\left(\chi^{2}\right)$ & $p\left(\chi^{2}\right)$ & $\mathrm{p}\left(\chi^{2}\right)$ \\
\hline Dia & & & 0.0249 & & & 0.0375 & & $\underline{0.0000}$ \\
\hline $\operatorname{Dia}^{1}$ & $0.010 \pm 0.003$ & ns & & $0.024 \pm 0.007$ & $\underline{0.0005}$ & & $\underline{0.0002}$ & \\
\hline$D_{i a}{ }^{2}$ & $0.091 \pm 0.017$ & $\underline{0.0006}$ & & $0.121 \pm 0.005$ & ns & & 0.0045 & \\
\hline$D i a^{4}$ & $0.658 \pm 0.011$ & ns & & $0.554 \pm 0.017$ & ns & & $\underline{0.0000}$ & \\
\hline $\operatorname{Dia}^{6}$ & $0.216 \pm 0.012$ & ns & & $0.279 \pm 0.020$ & 0.0022 & & $\underline{0.0000}$ & \\
\hline $\operatorname{Dia}^{7}$ & $0.017 \pm 0.002$ & ns & & $0.013 \pm 0.004$ & ns & & ns & \\
\hline Est-D & & & 0.0430 & & & ns & & $\underline{0.0000}$ \\
\hline Est-D $D^{1}$ & $0.002 \pm 0.001$ & 0.0351 & & $0.025 \pm 0.006$ & ns & & $\underline{0.0000}$ & \\
\hline Est-D $D^{2}$ & $0.039 \pm 0.004$ & ns & & $0.017 \pm 0.002$ & ns & & $\overline{0.0032}$ & \\
\hline Est-D $D^{4}$ & $0.901 \pm 0.009$ & 0.0019 & & $0.944 \pm 0.006$ & ns & & $\underline{0.0000}$ & \\
\hline Est- $D^{6}$ & $0.046 \pm 0.005$ & ns & & $0.014 \pm 0.003$ & ns & & $\underline{0.0000}$ & \\
\hline$I d h$ & & & ns & & & ns & & ns \\
\hline$I d h^{2}$ & $0.102 \pm 0.005$ & ns & & $0.097 \pm 0.007$ & ns & & ns & \\
\hline$I d h^{3}$ & $0.885 \pm 0.005$ & ns & & $0.888 \pm 0.008$ & ns & & ns & \\
\hline$I d h^{4}$ & $0.011 \pm 0.003$ & ns & & $0.011 \pm 0.003$ & ns & & ns & \\
\hline Lap-1 & & & 0.0410 & & & ns & & $\underline{0.0000}$ \\
\hline Lap $-1^{2}$ & $0.009 \pm 0.002$ & ns & & $0.019 \pm 0.004$ & ns & & 0.0408 & \\
\hline Lap $-1^{3}$ & $0.031 \pm 0.005$ & 0.0434 & & $0.039 \pm 0.009$ & 0.0131 & & 0.0058 & \\
\hline Lap-1 ${ }^{4}$ & $0.023 \pm 0.004$ & 0.0277 & & $0.079 \pm 0.006$ & ns & & $\underline{0.0000}$ & \\
\hline$L a p-1^{5}$ & $0.410 \pm 0.011$ & ns & & $0.398 \pm 0.011$ & ns & & $\mathrm{ns}$ & \\
\hline Lap- $1^{6}$ & $0.491 \pm 0.013$ & ns & & $0.437 \pm 0.009$ & ns & & 0.0250 & \\
\hline Lap $-1^{7}$ & $0.033 \pm 0.003$ & ns & & $0.026 \pm 0.004$ & ns & & ns & \\
\hline Lap-2 & & & ns & & & ns & & $\underline{0.0070}$ \\
\hline Lap $-2^{2}$ & $0.031 \pm 0.004$ & ns & & $0.028 \pm 0.005$ & ns & & ns & \\
\hline$L a p-2^{3}$ & $0.498 \pm 0.008$ & ns & & $0.484 \pm 0.012$ & ns & & ns & \\
\hline Lap $-2^{5}$ & $0.439 \pm 0.009$ & ns & & $0.420 \pm 0.009$ & ns & & ns & \\
\hline Lap $-2^{7}$ & $0.028 \pm 0.003$ & ns & & $0.066 \pm 0.007$ & ns & & $\underline{0.0000}$ & \\
\hline Mpi & & & $\underline{0.0020}$ & & & ns & & $\underline{0.0002}$ \\
\hline$M p i^{2}$ & $0.944 \pm 0.007$ & 0.0020 & & $0.965 \pm 0.008$ & ns & & $\underline{0.0002}$ & \\
\hline$M p i^{3}$ & $0.049 \pm 0.006$ & 0.0060 & & $0.034 \pm 0.008$ & ns & & $\underline{0.0011}$ & \\
\hline Odh & & & $\underline{0.0042}$ & & & 0.0220 & & $\underline{0.0000}$ \\
\hline$O d h^{3}$ & $0.558 \pm 0.013$ & 0.0045 & & $0.131 \pm 0.012$ & ns & & $\underline{0.0000}$ & \\
\hline$O d h^{6}$ & $0.128 \pm 0.008$ & 0.0293 & & $0.216 \pm 0.015$ & 0.0165 & & $\underline{0.0000}$ & \\
\hline$O d h^{8}$ & $0.295 \pm 0.008$ & ns & & $0.642 \pm 0.021$ & 0.0160 & & 0.0000 & \\
\hline $6 P g d h$ & & & ns & & & ns & & $\underline{0.0236}$ \\
\hline $6 P g d h^{2}$ & $0.034 \pm 0.004$ & ns & & $0.016 \pm 0.002$ & ns & & 0.0467 & \\
\hline $6 P g d h^{4}$ & $0.926 \pm 0.005$ & ns & & $0.956 \pm 0.004$ & ns & & 0.0246 & \\
\hline $6 P g d h^{6}$ & $0.023 \pm 0.004$ & 0.0371 & & $0.018 \pm 0.003$ & ns & & ns & \\
\hline Pgi & & & 0.0450 & & & ns & & $\underline{0.0000}$ \\
\hline$P g i^{2}$ & $0.021 \pm 0.004$ & 0.0223 & & $0.006 \pm 0.002$ & ns & & $\underline{0.0001}$ & \\
\hline $\mathrm{Pgi}^{3}$ & $0.063 \pm 0.005$ & ns & & $0.030 \pm 0.003$ & ns & & 0.0045 & \\
\hline$P g i^{4}$ & $0.559 \pm 0.018$ & 0.0013 & & $0.788 \pm 0.012$ & $\mathrm{~ns}$ & & $\underline{0.0000}$ & \\
\hline $\mathrm{Pgi}^{6}$ & $0.255 \pm 0.010$ & ns & & $0.146 \pm 0.012$ & $\mathrm{~ns}$ & & 0.0000 & \\
\hline $\mathrm{Pgi}^{7}$ & $0.065 \pm 0.006$ & ns & & $0.025 \pm 0.004$ & $\mathrm{~ns}$ & & 0.0000 & \\
\hline $\mathrm{Pgi}^{8}$ & $0.020 \pm 0.005$ & 0.0054 & & $0.003 \pm 0.001$ & ns & & $\underline{0.0000}$ & \\
\hline Pgm & & & ns & & & ns & & $\underline{0.0098}$ \\
\hline $\mathrm{Pgm}^{2}$ & $0.014 \pm 0.003$ & ns & & $0.037 \pm 0.002$ & ns & & 0.0278 & \\
\hline $\mathrm{Pgm}^{3}$ & $0.108 \pm 0.005$ & ns & & $0.134 \pm 0.005$ & ns & & ns & \\
\hline $\mathrm{Pgm}^{4}$ & $0.601 \pm 0.011$ & ns & & $0.523 \pm 0.012$ & ns & & $\underline{0.0009}$ & \\
\hline $\mathrm{Pgm}^{6}$ & $0.257 \pm 0.010$ & ns & & $0.282 \pm 0.008$ & ns & & ns & \\
\hline Stdh & & & $\underline{0.0039}$ & & & ns & & $\underline{0.0000}$ \\
\hline$S t d h^{2}$ & $0.116 \pm 0.008$ & ns & & $0.184 \pm 0.011$ & ns & & $\underline{0.0000}$ & \\
\hline$S t d h^{4}$ & $0.115 \pm 0.012$ & & 0.0292 & $0.115 \pm 0.014$ & 0.0105 & & 0.0035 & \\
\hline$S t d h^{5}$ & $0.026 \pm 0.004$ & & ns & $0.007 \pm 0.003$ & ns & & 0.0057 & \\
\hline$S t d h^{6}$ & $0.081 \pm 0.005$ & & ns & $0.014 \pm 0.006$ & ns & & 0.0000 & \\
\hline$S t d h^{7}$ & $0.623 \pm 0.016$ & & 0.0442 & $0.660 \pm 0.014$ & 0.0442 & & 0.0219 & \\
\hline$S t d h^{8}$ & $0.021 \pm 0.005$ & & 0.0165 & $0.011 \pm 0.003$ & 0.0165 & & 0.0060 & \\
\hline
\end{tabular}



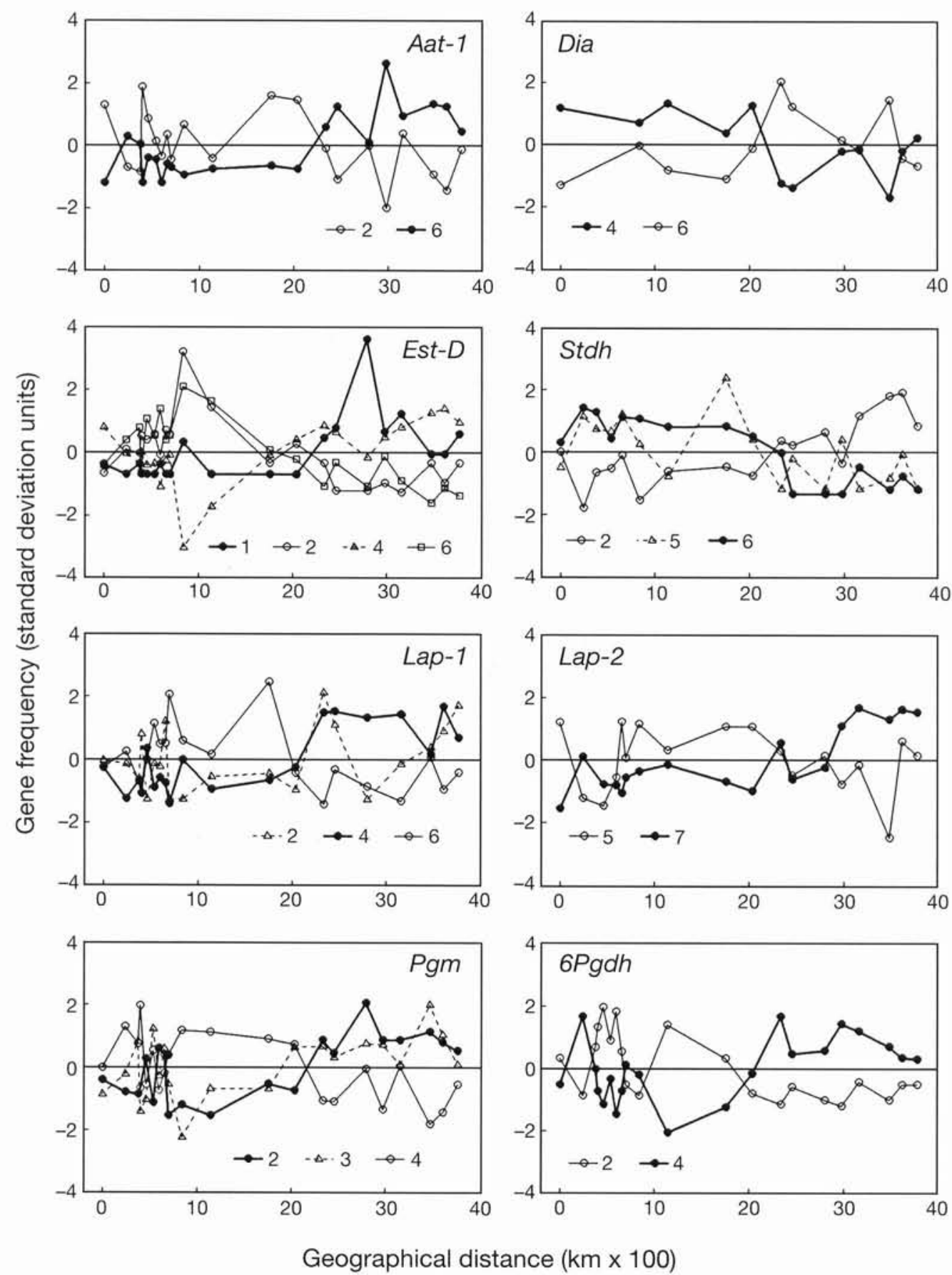

Fig. 3. Mytilus galloprovincialis. Geographical variation in allele frequencies at loci Aat-1, Est-D, Lap-1, Pgm, Dia, Stdh, Lap-2 and $6 P g d h$. Only the most frequent allele at each locus and alleles with significant geographical heterogeneity are plotted

into 3 arbitrary groups. Two of these classes included the 11 loci which exhibited a significant sharp discontinuity in southeastern Spain, and the third one included the 4 loci which did not show this change.

Class I loci showed the greatest abrupt variation. At each locus, 2 or more common alleles were strikingly affected by the genetic break. Loci included in this class are Odh, Pgi and Ap (Fig. 2). The discontinuity was particularly strong for Odh. At this locus, the frequency of the $O d h^{3}$ allele ranged from 0.500 to 0.658 throughout all the samples from Santander to Almeria, with an average value of $0.558 \pm 0.013$. East of Almeria, the frequency of this allele decreased abruptly from 0.658 to 0.107 , and remained fairly invariant within area 2 , with a mean frequency of $0.131 \pm 0.012$. The loci Ap and Pgi exhibited a concordant pattern of 


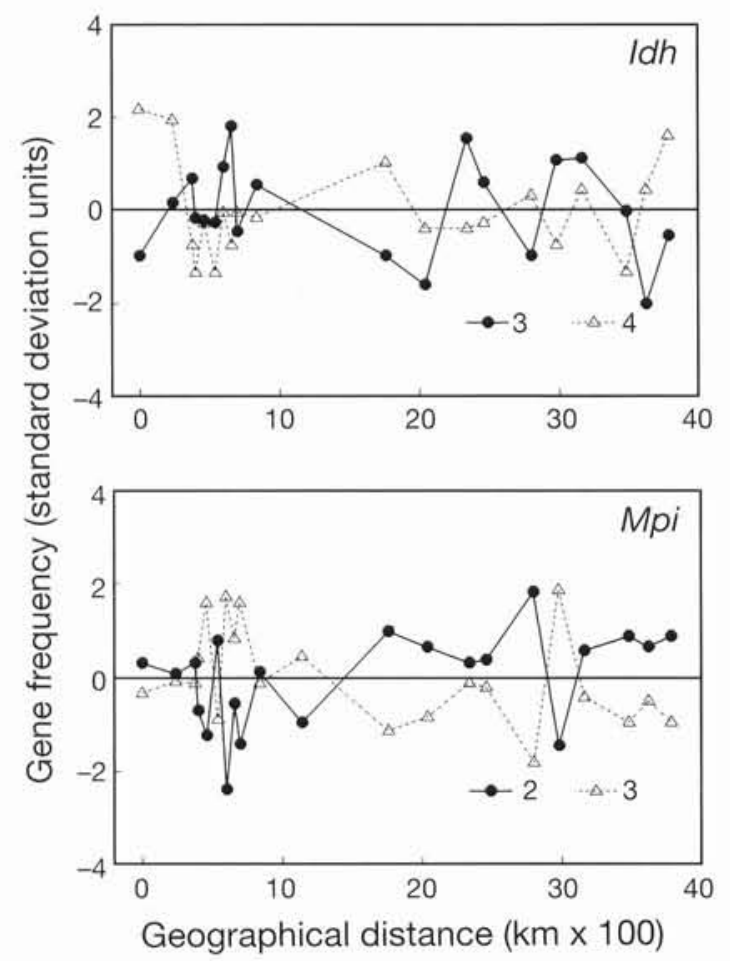

Fig. 4. Mytilus galloprovincialis. Geographical variation in allele frequencies at loci Idh and Mpi. Only most frequent alleles are plotted

abrupt transition in southeastern Spain, with an average change in frequency for the alleles most affected by the genetic break of $0.247\left(A p^{3}\right)$ and $\left.0.229\left(P^{-4}\right)^{4}\right)$.

Class II loci presented an abrupt change in southeastern Spain of a lesser magnitude. Loci belonging to this class are Aat-1, Est-D, Dia, Lap-1, Lap-2, Pgm, $6 P g d h$ and Stdh (Fig. 3). In these loci, the mean change in the frequency of the alleles more affected by the genetic discontinuity, ranged from 0.104 for $\mathrm{Dia}^{4}$ to 0.023 for Est- $D^{1}$ and $P_{g m}{ }^{2}$. Although the gene-frequency differences are modest in absolute terms, they are high in relative terms as measured by standard deviation units (SDU). When this transformation is used, a similar abrupt change across loci is apparent (Fig. 3), with an average variation of $1.68 \pm 0.09 \mathrm{SDU}$ for the most affected alleles at each locus, which is not significantly different from the average of $1.96 \pm 0.09$ SDU observed for class I loci $(U$-test $=1.04, p>0.05)$

Class III loci did not exhibit any significant genetic discontinuity in allelic frequencies throughout all the geographic areas studied. These loci were monomorphic (Aat-2 and Sod) or presented a very frequent allele having the same electrophoretic mobility in both areas (Idh and Mpi) (Fig. 4).

The amount of genetic differentiation was small considering the large geographical area sampled. Only about $3 \%$ of the total gene diversity was due to differences among populations (Table 3 ). However, the magnitude of the $\mathrm{G}_{\mathrm{ST}}$ estimates was very heterogeneous across loci, with class I loci exhibiting the highest values: Odh (0.124), Pgi (0.040) and Ap (0.033). By contrast, the remaining 10 polymorphic loci displayed very small and homogeneous $\mathrm{G}_{\mathrm{ST}}$ estimates, most of them very close to 0.01 . The divergence between area 1 and area 2 samples explains over $75 \%$ of the total heterogeneity, and is mainly attributable to class I loci. The degree of subdivision within areas explains the remaining $25 \%$ of the total differentiation, and the contribution of all loci is similar, including Odh, Pgi and Ap.

The abrupt change in allele frequencies in southeastern Spain is graphically summarised in the UPGMA dendrogram constructed from the 10 populations analyzed for the whole set of loci (Fig. 5A). All the samples collected from Santander to Almeria clustered in one phenetic group (area 1), and all the mussels taken from Alicante to Livorno clustered in the other (area 2). Within each cluster, mussel populations displayed a high genetic similarity, with a mean genetic distance for within-group comparisons of $0.001 \pm$ 0.0002 . This average increased to $0.032 \pm 0.001$ when pairs of populations from different areas were compared. The separation of area 1 and area 2 samples into 2 distinct groups is also mostly due to class I loci. When these loci are removed, the genetic distance between both areas decreases, but the same pattern of grouping persists at a lower clustering level, indicating the effect of other loci (Fig. 5B).

The estimates of the number of migrant individuals per generation $(\mathrm{Nm})$ for area 1 and area 2 samples were 35.5 and 41.4 respectively. These values are very close to those previously reported in natural popula-

Table 3. Mytilus galloprovincialis. Gene diversity coefficients between populations $\left(\mathrm{G}_{\mathrm{ST}}\right)$, between areas $\left(\mathrm{G}_{\mathrm{AT}}\right)$ and between populations within areas $\left(\mathrm{G}_{\mathrm{SA}}\right)$

\begin{tabular}{|lccc|}
\hline Locus & $\mathrm{G}_{\mathrm{SA}}$ & $\mathrm{G}_{\mathrm{AT}}$ & $\mathrm{G}_{\mathrm{ST}}$ \\
\hline Aat-1 & 0.007 & 0.003 & 0.010 \\
Ap & 0.006 & 0.027 & 0.033 \\
Dia & 0.007 & 0.007 & 0.014 \\
Est-D & 0.008 & 0.006 & 0.014 \\
Idh & 0.004 & 0.000 & 0.004 \\
Lap-1 & 0.006 & 0.002 & 0.008 \\
Lap-2 & 0.003 & 0.001 & 0.004 \\
Mpi & 0.012 & 0.002 & 0.014 \\
Odh & 0.009 & 0.115 & 0.124 \\
GPgdh & 0.005 & 0.003 & 0.008 \\
Pgi & 0.008 & 0.032 & 0.040 \\
Pgm & 0.005 & 0.003 & 0.008 \\
Stdh & 0.009 & 0.005 & 0.014 \\
Mean & 0.007 & 0.022 & 0.029 \\
\hline
\end{tabular}




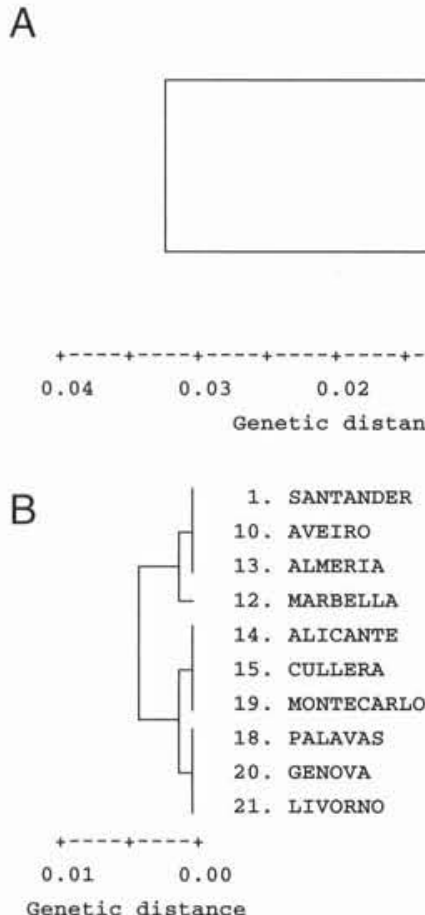

tions of Mytilus edulis ( $\mathrm{Nm}=42.0$; Slatkin 1985a), and are indicative of a high gene flow, in accordance with the genetic homogeneity detected within each area. The estimate of $\mathrm{Nm}$ for the whole set of populations $(\mathrm{Nm}=8.4$ ) was approximately 4 to 5 times lower than the gene flow between populations within each area. When class I loci are excluded, the total $\mathrm{Nm}$ estimate (27.5) is also smaller than those obtained for area 1 (35.5) and area 2 (41.4). These results suggest some degree of isolation between the 2 groups of populations, although they are still indicative of a substantial gene flow. Nevertheless, the absolute magnitude of the total $\mathrm{Nm}$ estimate must be regarded with caution for several reasons. First of all, indirect methods of $\mathrm{Nm}$ estimation reflect the historical average of gene flow among populations that is necessary to generate the observed pattern of differentiation, and this usually results in an overestimate of the real gene flow (Slatkin 1985b). Secondly, the validity of the estimate of $\mathrm{Nm}$ depends on the applicability of the underlying assumptions, such as neutral loci or an island model of population structure. Such assumptions do not seem appropiate in the present context, since the discontinuities in allelic frequencies could be due to the absence of random mating between populations from areas 1 and 2, to selection or to a combination of both factors.

The presence of a restriction to gene flow is also suggested by the fact that a total of 15 rare alleles were not shared among area 1 and area 2 populations. Area 1 exhibited 11 of these exclusive alleles. Most of them were detected more than once in several populations, and their frequency was no higher than 0.025 nor lower than 0.005 . The most representative distribution was that of the Aat $-1^{1}$ allele, which was present in 9 samples within area 1 , with an average frequency of $0.012 \pm 0.002$. The 4 exclusive alleles found within area 2 were detected only once in an unique population.

Extensive heterozygote deficiencies or linkage disequilibrium within the transition zone at loci with strongest differentiation (class I loci), would indicate restriction of interbreeding among populations belonging to areas 1 and 2 . Out of 12 tests showing significant deficiencies of heterozygotes after Bonferroni adjustment, 5 were observed in the samples closest to the genetic breakpoint: Almeria, Alicante and Cullera. However, only 2 correspond to loci with high genetic divergence: Odh and Pgi, in the Cullera sample (data detailed in Quesada 1992). Moreover, significant heterozygote deficiencies were also observed for Pgi outside of the transition zone in Rande and Genova samples, more than $1000 \mathrm{~km}$ away from the mussel breakpoint. These results clearly indicate that some mixing occurs in the transition zone, but that deficiencies of heterozygotes are no so extensive as would be expected in a non-interbreeding mixture of populations from both areas. In addition, tests of non-random assortment of genotypes showed little evidence for systematic associations between loci. Out of the 57 tests of genotypic dilocus associations performed between Odh, Pgi and Ap, only 2 were significant. These significant associations were detected for the pairwise combinations Ap-Odh in Livorno, and for Ap-Pgi in Montecarlo, very far from the transition region in southeastern Spain.

\section{DISCUSSION}

This allozyme survey in Mytilus galloprovincialis shows a major genetic break in southeastern Spain that delimits 2 groups of populations with a high internal homogeneity. Sharp discontinuities detected in allele frequencies at 11 of 13 polymorphic loci coincide spatially in the region between Almeria and Alicante, over $300 \mathrm{~km}$ apart, which is a relatively narrow zone with respect to the dispersal distance. Roughly $75 \%$ of the total genetic differentiation was attributable to the divergence between both areas. However, the genetic distance between these 2 regions was small $(0.03)$, in the range expected for conspecific populations ( 0.0 to 0.05; Ferguson 1980), and much lower than genetic distances reported between the well-recognized Mytilus taxa, where distances based on 16 to 23 loci ranged from 0.16 to 0.28 (Skibinski et al. 1980, Grant \& Cherry 1985, Väinölä \& Hvilson 1991). Moreover, the 
observed pattern of heterozygote deficiencies and the absence of significant associations among genotypes near the transition zone suggest that the 2 types of mussels successfully interbreed. Thus, our results are far from suggesting differentiation at the species level, in agreement with earlier taxonomic studies on European M. galloprovincialis, based on morphological and allozyme data (Koehn 1991, Gardner 1992, Gosling 1992b, Seed 1992).

The results of this study contrast with previous surveys on Mytilus of fairly genetic homogeneity over vast geographical distances, except the sharp cline in $M$. edulis for the Lap locus at the entrance to Long Island Sound (USA) and at Cape Cod (Massachusetts, USA) (Koehn 1991, Gosling 1992c). Our data demonstrate, for the first time, that extensive differentiation at many loci is possible in conspecific populations of Mytilus over relatively short distances. On the other hand, the sharp multilocus cline in $M$. galloprovincialis represents an uncommon result in marine organisms with larval dispersal, since only a few studies report allozyme clines at many loci (Väinölä \& Varvio 1989, Ropson et al. 1990), and none involve well-defined narrow contact zones.

Previous surveys of allozymic variation in Mytilus galloprovincialis have already revealed some evidence of genetic divergence for 1 to 2 loci in disjunct Atlantic and Mediterranean populations (Varvio et al. 1988, Sanjuan et al. 1990). These earlier results thus support our finding of genetically distinct eastern and western breakpoint populations in European M. galloprovincialis. The present study extends the differentiation up to 11 loci, and determines the transition zone and type of change between these populations.

Since Mytilus galloprovincialis is characterized by a long pelagic larvae stage of around 3 to 4 wk (Lutz \& Kennish 1992), the sharp genetic change observed in southeastern Spain could not persists without strong natural selection and/or the presence of environmental factors limiting larval dispersal and gene flow. Three observations strongly support the hypothesis that there is restriction of gene flow between the populations belonging to both areas: (1) The change occurs at many loci, as expected from an isolation process affecting the entire genome. (2) The genetic break is concordant with geographical position for all 11 loci, that exhibit a parallel abrupt change with no intermediate frequencies. (3) Many rare alleles (14\% of the total) are not shared between the 2 areas. Alternatively, estimates of gene flow, although consistent with a reduction in migration, indicate that gene flow is still substantial.

Theoretically, if no external selective differences existed, the position of the transition zone would be attracted to an area where gene flow is reduced (Endler 1977, Barton \& Hewitt 1985). Much evidence suggests that the transition zone could, in fact, represent an ecological barrier, and restrict gene flow between Mytilus populations located at both sides of the genetic breakpoint. Recent studies of satellite imagery indicate that the main path of inflowing Atlantic water into the Mediterranean through the Straits of Gibraltar is around 2 large anticyclonic gyres in the Alboran Sea (Tintore et al. 1988). The convergence of the Eastern Gyre with the resident Mediterranean water near Cape Gata (Almeria) determines a well-defined frontal zone (Fig. 1), where the main current is deflected southward toward Oran (Algeria), then creating the Algerian Current (Arnone \& La Violette 1986, Tintore et al. 1988, Arnone et al. 1990). This oceanographic front (the Almeria-Oran Front) is associated with strong southeastward currents (average speeds of $40 \mathrm{~cm} \mathrm{~s}^{-1}$ and maximum speeds of $60 \mathrm{~cm} \mathrm{~s}^{-1}$ ), and dramatic changes in salinity ( 2 psu) and temperature $\left(1.4^{\circ} \mathrm{C}\right)$ within a $2 \mathrm{~km}$ distance, with effects that involve the upper $300 \mathrm{~m}$ water layer (Lohrenz et al. 1988, Tintore et al. 1988, Arnone et al. 1990). It is suggested that the direction of the strong surface water currents, coupled with the ecological gradients associated with this oceanographic boundary pose a barrier to the dispersal of planktonic mussel larvae, physiologically acclimated to their native environment, and intolerant to sudden environmental changes (Bayne 1965, 1976, Lutz \& Kennish 1992). Thus, crossing this oceanographic front might be fatal to larvae, irrespective of their genotype, so that apparent dispersal capacity would not be realized.

A second factor supporting an ecological barrier is that the zone of genetic change corresponds to an area of low density for mussel populations (Quesada 1992). In fact, no evidence of mussel presence was found along the coastline between Almeria and Alicante after detailed sampling. Garcia-Raso et al. (1992) and fishermen confirm this result. The extensive extinctions of filtering marine organisms associated with the catastrophic-storm-related phenomena that periodically occur in this region (Garcia-Raso et al. 1992), in conjunction with extremely high summer temperatures and aridity that may reduce mussel survival (Capel 1981, Tsuchiya 1983, Seed \& Suchanek 1992), suggest that the observed discontinuity in distribution corresponds to an area unsuitable for mussels. In conclusion, the coastline between Almeria and Alicante represents a density trough, probably contributing to isolation among mussel populations and providing another cause of coincident clines (Hewitt 1989, Quesada 1992).

No significant clinal variation was found within the western or eastern breakpoint regions, which display similar but smaller environmental gradients (such as salinity and temperature), to those observed in the 
transition zone (Collier 1970, Rodriguez 1982, Tintore et al. 1988). This could indicate that most of the divergence between regions does not reflect an adaptive response to an underlying environmental gradient. Most probably, however, mussel populations on both sides of the genetic breakpoint are also genetically adapted to their present native environment, although much of this adaptedness could have been acquired after isolation. If such a situation occurs, coincident clines involving multiple loci themselves can act as barriers to gene flow, even for neutral loci, due to linkage disequilibrium between the selected and neutral loci (Barton 1979, 1982, Barton \& Hewitt 1985). In summary, we suggest that the genetic breakpoint corresponds closely in geographical position to an ecological barrier that, perhaps in conjunction with coincident clines, restricts gene flow among mussel populations from western and eastern regions. This means that functionally independent ecological and genetic factors may act together in the maintenance of genetic isolation, and in determining the position of the contact zone.

Southeastern Spain is an area widely recognized as a biogeographic border between Mediterranean and Atlantic biotic-communities (Rodriguez et al. 1979, Conde \& Seoane 1982, Peres 1989). Because the intraspecific break in the genus Mytilus is closely coincident with this biogeographic limit, it is suggested that both phenomena may be due to a common set of factors. A similar geographical correspondence between intraspecific divergence and this distributional limit has been observed for the barnacle Chthamalus montagui (Dando \& Southward 1981) and the fish Gobious paganellus (Amores et al. 1990), as evidenced by allozyme and chromosome polymorphisms respectively. Hence, similar historical and contemporary phenomena may be responsible for these patterns of variation. The picture in southeastern Spain resembles that observed for other marine species in other well- defined biogeographic borders (Väinölä \& Varvio 1989, Avise 1992). Thus, our results support the hypothesis suggested by Avise et al. (1987), that when phylogenetic discontinuities occur within widely distributed species, they tend to be concordant with the boundaries between traditional recognized zoogeographic provinces.

The large-scale climatic and eustatic changes which occurred in the Atlantic and Mediterranean areas over the Pleistocene could have initiated the genetic divergence among Mytilus populations (Quesada 1992). In this period the Mediterranean was affected by wide temperature glacial/interglacial fluctuations (Thunell 1979), and water exchange between the Atlantic and Mediterranean was much altered (Pielou 1979, Loubere 1982, Rodriguez 1982). Moreover, the narrow pathways between the various basins of the Mediterranean must frequently have been narrower and more restricted that at present due to the eustatic lowering of the Glacial sea levels (Thiede 1978, Pielou 1979, Rodriguez 1982), thus allowing Mytilus populations to have split. The transition zone in southeastern Spain might represent a post-glacial contact of allopatrically divergent populations, when oceanographic circulation became similar to present. However, the alternative hypothesis of an in situ origin for the mussel genetic divergence cannot be excluded with the present data set.

In conclusion, we propose that the genetic divergence in Mytilus populations is maintained by contemporary influences on gene flow due to an ecological barrier, perhaps in combination with selective pressures associated with water mass differences. The results of this study support that extrinsic forces, such as climatic and oceanographic events, may be the major causal elements determining genetic differentiation and geographical distribution among populations of marine species with large population sizes and pelagic larval dispersal.

Appendix. Allele frequencies and sample sizes $(\mathrm{N})$ of Mytilus galloprovincialis populations. Population numbers are as in Fig. 1

\begin{tabular}{|c|c|c|c|c|c|c|c|c|c|c|c|}
\hline Locus & Population & 1 & 2 & 3 & 4 & $\begin{array}{c}\text { Allele } \\
5\end{array}$ & 6 & 7 & 8 & 9 & $\mathrm{~N}$ \\
\hline Aat -1 & $\begin{array}{l}\text { 1. Santander } \\
\text { 2. Ribadeo } \\
\text { 3. Malata } \\
\text { 4. Sada } \\
\text { 5. Laxe } \\
\text { 6. Portosin } \\
\text { 7. Carril } \\
\text { 8. Rande } \\
\text { 9. Silleiro } \\
\text { 10. Aveiro } \\
\text { 11. Sesimbra } \\
\text { 12. Marbella } \\
\text { 13. Almeria }\end{array}$ & $\begin{array}{l}0.010 \\
0.000 \\
0.010 \\
0.000 \\
0.016 \\
0.025 \\
0.013 \\
0.016 \\
0.010 \\
0.005 \\
0.000 \\
0.000 \\
0.006\end{array}$ & $\begin{array}{l}0.954 \\
0.904 \\
0.900 \\
0.969 \\
0.943 \\
0.925 \\
0.913 \\
0.930 \\
0.910 \\
0.938 \\
0.911 \\
0.962 \\
0.958\end{array}$ & $\begin{array}{l}0.000 \\
0.000 \\
0.000 \\
0.000 \\
0.000 \\
0.000 \\
0.000 \\
0.000 \\
0.015 \\
0.000 \\
0.000 \\
0.011 \\
0.003\end{array}$ & $\begin{array}{l}0.036 \\
0.066 \\
0.065 \\
0.031 \\
0.021 \\
0.035 \\
0.060 \\
0.033 \\
0.040 \\
0.046 \\
0.080 \\
0.016 \\
0.024\end{array}$ & $\begin{array}{l}0.000 \\
0.000 \\
0.000 \\
0.000 \\
0.005 \\
0.000 \\
0.013 \\
0.008 \\
0.015 \\
0.005 \\
0.000 \\
0.000 \\
0.000\end{array}$ & $\begin{array}{l}0.000 \\
0.030 \\
0.025 \\
0.000 \\
0.016 \\
0.015 \\
0.000 \\
0.012 \\
0.010 \\
0.005 \\
0.009 \\
0.011 \\
0.009\end{array}$ & $\begin{array}{l}- \\
- \\
- \\
- \\
- \\
- \\
- \\
- \\
- \\
-\end{array}$ & $\begin{array}{l}- \\
- \\
- \\
- \\
- \\
- \\
- \\
- \\
- \\
- \\
-\end{array}$ & $\begin{array}{l}- \\
- \\
- \\
- \\
- \\
- \\
- \\
- \\
- \\
-\end{array}$ & $\begin{array}{r}98 \\
99 \\
100 \\
16 \\
96 \\
100 \\
75 \\
122 \\
100 \\
97 \\
56 \\
92 \\
167\end{array}$ \\
\hline
\end{tabular}


Appendix (continued)

\begin{tabular}{|c|c|c|c|c|c|c|c|c|c|c|c|}
\hline Locus & Population & 1 & 2 & 3 & 4 & $\begin{array}{c}\text { Allele } \\
5\end{array}$ & 6 & 7 & 8 & 9 & $\mathrm{~N}$ \\
\hline Aat-1 & $\begin{array}{l}\text { 14. Alicante } \\
\text { 15. Cullera } \\
\text { 16. Garraf } \\
\text { 17. LLansa } \\
\text { 18. Palavas } \\
\text { 19. Montecarlo } \\
\text { 20. Genova } \\
\text { 21. Livorno }\end{array}$ & $\begin{array}{l}0.000 \\
0.000 \\
0.000 \\
0.000 \\
0.000 \\
0.000 \\
0.000 \\
0.000\end{array}$ & $\begin{array}{l}0.919 \\
0.894 \\
0.921 \\
0.871 \\
0.931 \\
0.898 \\
0.885 \\
0.918\end{array}$ & $\begin{array}{l}0.000 \\
0.000 \\
0.000 \\
0.005 \\
0.005 \\
0.000 \\
0.000 \\
0.000\end{array}$ & $\begin{array}{l}0.041 \\
0.053 \\
0.026 \\
0.041 \\
0.021 \\
0.034 \\
0.060 \\
0.049\end{array}$ & $\begin{array}{l}0.005 \\
0.004 \\
0.026 \\
0.005 \\
0.000 \\
0.017 \\
0.005 \\
0.000\end{array}$ & $\begin{array}{l}0.036 \\
0.049 \\
0.026 \\
0.077 \\
0.043 \\
0.051 \\
0.049 \\
0.033\end{array}$ & $\begin{array}{l}- \\
- \\
- \\
- \\
- \\
-\end{array}$ & $\begin{array}{l}- \\
- \\
- \\
- \\
- \\
-\end{array}$ & $\begin{array}{l}- \\
- \\
- \\
- \\
- \\
-\end{array}$ & $\begin{array}{r}111 \\
113 \\
19 \\
97 \\
94 \\
88 \\
91 \\
91\end{array}$ \\
\hline Aat-2 & $\begin{array}{l}\text { 1. Santander } \\
\text { 2. Ribadeo } \\
\text { 3. Malata } \\
\text { 4. Sada } \\
\text { 5. Laxe } \\
\text { 6. Portosin } \\
\text { 7. Carril } \\
\text { 8. Rande } \\
\text { 9. Silleiro } \\
\text { 10. Aveiro } \\
\text { 11. Sesimbra } \\
\text { 12. Marbella } \\
\text { 13. Almeria } \\
\text { 14. Alicante } \\
\text { 15. Cullera } \\
\text { 16. Garraf } \\
\text { 17. LLansa } \\
\text { 18. Palavas } \\
\text { 19. Montecarlo } \\
\text { 20. Genova } \\
\text { 21. Livorno }\end{array}$ & $\begin{array}{l}0.000 \\
0.005 \\
0.005 \\
0.000 \\
0.006 \\
0.000 \\
0.006 \\
0.004 \\
0.000 \\
0.012 \\
0.011 \\
0.006 \\
0.000 \\
0.000 \\
0.000 \\
0.025 \\
0.011 \\
0.000 \\
0.009 \\
0.000 \\
0.000\end{array}$ & $\begin{array}{l}1.000 \\
0.995 \\
0.995 \\
1.000 \\
0.994 \\
1.000 \\
0.994 \\
0.996 \\
1.000 \\
0.988 \\
0.989 \\
0.994 \\
1.000 \\
1.000 \\
1.000 \\
0.975 \\
0.989 \\
1.000 \\
0.983 \\
1.000 \\
1.000\end{array}$ & $\begin{array}{l}0.000 \\
0.000 \\
0.000 \\
0.000 \\
0.000 \\
0.000 \\
0.000 \\
0.000 \\
0.000 \\
0.000 \\
0.000 \\
0.000 \\
0.000 \\
0.000 \\
0.000 \\
0.000 \\
0.000 \\
0.000 \\
0.009 \\
0.000 \\
0.000\end{array}$ & $\begin{array}{l}- \\
- \\
- \\
- \\
- \\
- \\
- \\
- \\
- \\
- \\
- \\
- \\
- \\
- \\
- \\
- \\
-\end{array}$ & $\begin{array}{l}- \\
- \\
- \\
- \\
- \\
- \\
z \\
- \\
- \\
- \\
- \\
- \\
- \\
- \\
- \\
-\end{array}$ & $\begin{array}{l}- \\
- \\
- \\
- \\
- \\
- \\
- \\
- \\
- \\
- \\
- \\
- \\
- \\
- \\
- \\
- \\
-\end{array}$ & $\begin{array}{l}- \\
- \\
- \\
- \\
- \\
- \\
- \\
- \\
- \\
- \\
- \\
- \\
- \\
- \\
- \\
-\end{array}$ & $\begin{array}{l}- \\
- \\
- \\
- \\
- \\
- \\
- \\
- \\
- \\
- \\
- \\
- \\
- \\
- \\
- \\
-\end{array}$ & $\begin{array}{l}- \\
- \\
- \\
- \\
- \\
- \\
- \\
- \\
- \\
- \\
- \\
- \\
- \\
- \\
- \\
- \\
- \\
- \\
- \\
- \\
-\end{array}$ & $\begin{array}{r}91 \\
98 \\
98 \\
20 \\
80 \\
92 \\
78 \\
121 \\
95 \\
82 \\
46 \\
86 \\
142 \\
118 \\
93 \\
20 \\
95 \\
91 \\
58 \\
90 \\
97\end{array}$ \\
\hline$A p$ & $\begin{array}{l}\text { 1. Santander } \\
\text { 2. Ribadeo } \\
\text { 3. Malata } \\
\text { 4. Sada } \\
\text { 5. Laxe } \\
\text { 6. Portosin } \\
\text { 7. Carril } \\
\text { 8. Rande } \\
\text { 9. Silleiro } \\
\text { 10. Aveiro } \\
\text { 11. Sesimbra } \\
\text { 12. Marbella } \\
\text { 13. Almeria } \\
\text { 14. Alicante } \\
\text { 15. Cullera } \\
\text { 16. Garraf } \\
\text { 17. LLansa } \\
\text { 18. Palavas } \\
\text { 19. Montecarlo } \\
\text { 20. Genova } \\
\text { 21. Livorno }\end{array}$ & $\begin{array}{l}0.000 \\
0.005 \\
0.011 \\
0.004 \\
0.005 \\
0.016 \\
0.000 \\
0.000 \\
0.011 \\
0.000 \\
0.007 \\
0.000 \\
0.000 \\
0.004 \\
0.000 \\
0.000 \\
0.000 \\
0.000 \\
0.000 \\
0.000 \\
0.000\end{array}$ & $\begin{array}{l}0.011 \\
0.000 \\
0.005 \\
0.012 \\
0.014 \\
0.000 \\
0.005 \\
0.000 \\
0.000 \\
0.005 \\
0.000 \\
0.038 \\
0.025 \\
0.013 \\
0.014 \\
0.000 \\
0.000 \\
0.011 \\
0.026 \\
0.005 \\
0.015\end{array}$ & $\begin{array}{l}0.409 \\
0.370 \\
0.404 \\
0.455 \\
0.384 \\
0.453 \\
0.429 \\
0.388 \\
0.417 \\
0.427 \\
0.426 \\
0.392 \\
0.374 \\
0.174 \\
0.177 \\
0.119 \\
0.196 \\
0.174 \\
0.117 \\
0.177 \\
0.170\end{array}$ & $\begin{array}{l}0.000 \\
0.005 \\
0.000 \\
0.000 \\
0.000 \\
0.005 \\
0.000 \\
0.000 \\
0.000 \\
0.000 \\
0.000 \\
0.000 \\
0.006 \\
0.000 \\
0.000 \\
0.000 \\
0.000 \\
0.000 \\
0.000 \\
0.000 \\
0.000\end{array}$ & $\begin{array}{l}0.344 \\
0.395 \\
0.298 \\
0.361 \\
0.361 \\
0.323 \\
0.344 \\
0.362 \\
0.394 \\
0.297 \\
0.338 \\
0.376 \\
0.368 \\
0.415 \\
0.392 \\
0.512 \\
0.430 \\
0.473 \\
0.413 \\
0.323 \\
0.390\end{array}$ & $\begin{array}{l}0.199 \\
0.195 \\
0.207 \\
0.127 \\
0.144 \\
0.151 \\
0.160 \\
0.179 \\
0.161 \\
0.188 \\
0.189 \\
0.172 \\
0.193 \\
0.220 \\
0.266 \\
0.179 \\
0.215 \\
0.163 \\
0.265 \\
0.318 \\
0.275\end{array}$ & $\begin{array}{l}0.022 \\
0.030 \\
0.074 \\
0.041 \\
0.083 \\
0.047 \\
0.057 \\
0.071 \\
0.017 \\
0.083 \\
0.041 \\
0.022 \\
0.034 \\
0.148 \\
0.136 \\
0.190 \\
0.152 \\
0.163 \\
0.168 \\
0.172 \\
0.130\end{array}$ & $\begin{array}{l}0.016 \\
0.000 \\
0.000 \\
0.000 \\
0.005 \\
0.005 \\
0.005 \\
0.000 \\
0.000 \\
0.000 \\
0.000 \\
0.000 \\
0.000 \\
0.025 \\
0.014 \\
0.000 \\
0.006 \\
0.016 \\
0.010 \\
0.005 \\
0.020\end{array}$ & $\begin{array}{l}- \\
- \\
- \\
- \\
- \\
- \\
- \\
- \\
- \\
- \\
- \\
- \\
- \\
- \\
- \\
- \\
- \\
- \\
- \\
- \\
-\end{array}$ & $\begin{array}{r}93 \\
100 \\
94 \\
122 \\
108 \\
96 \\
106 \\
112 \\
90 \\
96 \\
74 \\
93 \\
163 \\
118 \\
246 \\
42 \\
79 \\
92 \\
98 \\
96 \\
100\end{array}$ \\
\hline Dia & $\begin{array}{l}\text { 1. Santander } \\
\text { 10. Aveiro } \\
\text { 11. Sesimbra } \\
\text { 12. Marbella } \\
\text { 13. Almeria } \\
\text { 14. Alicante } \\
\text { 15. Cullera } \\
\text { 17. LLansa } \\
\text { 18. Palavas } \\
\text { 19. Montecarlo } \\
\text { 20. Genova } \\
\text { 21. Livorno }\end{array}$ & $\begin{array}{l}0.006 \\
0.005 \\
0.007 \\
0.021 \\
0.011 \\
0.004 \\
0.003 \\
0.026 \\
0.016 \\
0.044 \\
0.056 \\
0.020\end{array}$ & $\begin{array}{l}0.122 \\
0.068 \\
0.076 \\
0.146 \\
0.042 \\
0.092 \\
0.140 \\
0.123 \\
0.121 \\
0.133 \\
0.117 \\
0.120\end{array}$ & $\begin{array}{l}0.006 \\
0.016 \\
0.000 \\
0.000 \\
0.000 \\
0.000 \\
0.003 \\
0.006 \\
0.005 \\
0.000 \\
0.011 \\
0.020\end{array}$ & $\begin{array}{l}0.672 \\
0.641 \\
0.681 \\
0.620 \\
0.676 \\
0.519 \\
0.510 \\
0.584 \\
0.588 \\
0.487 \\
0.583 \\
0.610\end{array}$ & $\begin{array}{l}0.000 \\
0.000 \\
0.000 \\
0.005 \\
0.000 \\
0.000 \\
0.000 \\
0.000 \\
0.000 \\
0.000 \\
0.000 \\
0.005\end{array}$ & $\begin{array}{l}0.183 \\
0.250 \\
0.208 \\
0.193 \\
0.246 \\
0.362 \\
0.318 \\
0.260 \\
0.242 \\
0.329 \\
0.228 \\
0.215\end{array}$ & $\begin{array}{l}0.011 \\
0.021 \\
0.021 \\
0.016 \\
0.018 \\
0.023 \\
0.022 \\
0.000 \\
0.027 \\
0.006 \\
0.006 \\
0.010\end{array}$ & $\begin{array}{l}0.000 \\
0.000 \\
0.007 \\
0.000 \\
0.007 \\
0.000 \\
0.003 \\
0.000 \\
0.000 \\
0.000 \\
0.000 \\
0.000\end{array}$ & $\begin{array}{l}- \\
- \\
- \\
- \\
- \\
- \\
- \\
- \\
- \\
-\end{array}$ & $\begin{array}{r}90 \\
96 \\
72 \\
96 \\
142 \\
130 \\
157 \\
77 \\
91 \\
79 \\
90 \\
100\end{array}$ \\
\hline Est-D & $\begin{array}{l}\text { 1. Santander } \\
\text { 2. Ribadeo } \\
\text { 3. Malata } \\
\text { 4. Sada } \\
\text { 5. Laxe } \\
\text { 6. Portosin }\end{array}$ & $\begin{array}{l}0.005 \\
0.000 \\
0.005 \\
0.000 \\
0.000 \\
0.000\end{array}$ & $\begin{array}{l}0.020 \\
0.032 \\
0.030 \\
0.039 \\
0.037 \\
0.040\end{array}$ & $\begin{array}{l}0.000 \\
0.005 \\
0.005 \\
0.000 \\
0.000 \\
0.000\end{array}$ & $\begin{array}{l}0.944 \\
0.916 \\
0.905 \\
0.917 \\
0.903 \\
0.905\end{array}$ & $\begin{array}{l}0.005 \\
0.005 \\
0.005 \\
0.020 \\
0.005 \\
0.010\end{array}$ & $\begin{array}{l}0.025 \\
0.042 \\
0.050 \\
0.020 \\
0.056 \\
0.045\end{array}$ & $\begin{array}{l}0.000 \\
0.000 \\
0.000 \\
0.000 \\
0.000 \\
0.000\end{array}$ & $\begin{array}{l}0.000 \\
0.000 \\
0.000 \\
0.005 \\
0.000 \\
0.000\end{array}$ & $\begin{array}{l}0.000 \\
0.000 \\
0.000 \\
0.000 \\
0.000 \\
0.000\end{array}$ & $\begin{array}{r}99 \\
95 \\
100 \\
102 \\
108 \\
100\end{array}$ \\
\hline
\end{tabular}


Appendix (continued)

\begin{tabular}{|c|c|c|c|c|c|c|c|c|c|c|c|}
\hline Locus & Population & 1 & 2 & 3 & 4 & $\begin{array}{c}\text { Allele } \\
5\end{array}$ & 6 & 7 & 8 & 9 & $\mathrm{~N}$ \\
\hline \multirow[t]{15}{*}{ Est-D } & 7. Carril & 0.005 & 0.029 & 0.000 & 0.880 & 0.005 & 0.063 & 0.005 & 0.010 & 0.005 & 104 \\
\hline & 8. Rande & 0.000 & 0.042 & 0.000 & 0.908 & 0.008 & 0.042 & 0.000 & 0.000 & 0.000 & 120 \\
\hline & 9. Silleiro & 0.000 & 0.040 & 0.000 & 0.914 & 0.000 & 0.045 & 0.000 & 0.000 & 0.000 & 99 \\
\hline & 10. Aveiro & 0.016 & 0.083 & 0.005 & 0.813 & 0.000 & 0.078 & 0.000 & 0.000 & 0.005 & 96 \\
\hline & 11. Sesimbra & 0.000 & 0.054 & 0.000 & 0.858 & 0.020 & 0.068 & 0.000 & 0.000 & 0.000 & 74 \\
\hline & 12. Marbella & 0.000 & 0.025 & 0.005 & 0.914 & 0.020 & 0.035 & 0.000 & 0.000 & 0.000 & 99 \\
\hline & 13. Almeria & 0.000 & 0.035 & 0.000 & 0.931 & 0.006 & 0.029 & 0.000 & 0.000 & 0.000 & 173 \\
\hline & 14. Alicante & 0.018 & 0.025 & 0.000 & 0.946 & 0.000 & 0.011 & 0.000 & 0.000 & 0.000 & 138 \\
\hline & 15. Cullera & 0.023 & 0.011 & 0.000 & 0.939 & 0.000 & 0.027 & 0.000 & 0.000 & 0.000 & 280 \\
\hline & 16. Garraf & 0.067 & 0.011 & 0.000 & 0.911 & 0.000 & 0.011 & 0.000 & 0.000 & 0.000 & 45 \\
\hline & 17. LLansa & 0.021 & 0.015 & 0.000 & 0.933 & 0.000 & 0.031 & 0.000 & 0.000 & 0.000 & 97 \\
\hline & 18. Palavas & 0.030 & 0.010 & 0.000 & 0.944 & 0.000 & 0.015 & 0.000 & 0.000 & 0.000 & 99 \\
\hline & 19. Montecarlo & 0.010 & 0.025 & 0.000 & 0.960 & 0.005 & 0.000 & 0.000 & 0.000 & 0.000 & 100 \\
\hline & 20. Genova & 0.010 & 0.015 & 0.000 & 0.965 & 0.000 & 0.010 & 0.000 & 0.000 & 0.000 & 100 \\
\hline & 21. Livorno & 0.020 & 0.025 & 0.000 & 0.950 & 0.000 & 0.005 & 0.000 & 0.000 & 0.000 & 100 \\
\hline \multirow[t]{20}{*}{ Idh } & 1. Santander & 0.000 & 0.105 & 0.865 & 0.030 & 0.000 & 0.000 & - & - & - & 100 \\
\hline & 2. Ribadeo & 0.000 & 0.083 & 0.889 & 0.028 & 0.000 & 0.000 & - & - & - & 90 \\
\hline & 3. Malata & 0.000 & 0.095 & 0.900 & 0.005 & 0.000 & 0.000 & - & - & - & 100 \\
\hline & 4. Sada & 0.000 & 0.118 & 0.882 & 0.000 & 0.000 & 0.000 & - & - & - & 76 \\
\hline & 5. Laxe & 0.000 & 0.110 & 0.881 & 0.009 & 0.000 & 0.000 & - & - & - & 109 \\
\hline & 6. Portosin & 0.005 & 0.115 & 0.880 & 0.000 & 0.000 & 0.000 & - & - & - & 100 \\
\hline & 7. Carril & 0.000 & 0.084 & 0.905 & 0.011 & 0.000 & 0.000 & - & - & - & 95 \\
\hline & 8. Rande & 0.005 & 0.067 & 0.924 & 0.005 & 0.000 & 0.000 & - & - & - & 105 \\
\hline & 9. Silleiro & 0.000 & 0.113 & 0.876 & 0.011 & 0.000 & 0.000 & - & - & - & 93 \\
\hline & 10. Aveiro & 0.000 & 0.093 & 0.897 & 0.010 & 0.000 & 0.000 & - & - & - & 97 \\
\hline & 12. Marbella & 0.005 & 0.110 & 0.865 & 0.020 & 0.000 & 0.000 & - & - & - & 100 \\
\hline & 13. Almeria & 0.000 & 0.133 & 0.852 & 0.008 & 0.008 & 0.000 & - & - & - & 64 \\
\hline & 14. Alicante & 0.000 & 0.074 & 0.918 & 0.008 & 0.000 & 0.000 & - & - & - & 61 \\
\hline & 15. Cullera & 0.000 & 0.093 & 0.898 & 0.009 & 0.000 & 0.000 & - & - & - & 54 \\
\hline & 16. Garraf & 0.000 & 0.122 & 0.865 & 0.014 & 0.000 & 0.000 & - & - & - & 37 \\
\hline & 17. LLansa & 0.000 & 0.087 & 0.908 & 0.005 & 0.000 & 0.000 & - & - & - & 98 \\
\hline & 18. Palavas & 0.000 & 0.071 & 0.909 & 0.015 & 0.000 & 0.005 & - & - & - & 99 \\
\hline & 19. Montecarlo & 0.005 & 0.110 & 0.885 & 0.000 & 0.000 & 0.000 & - & _ & - & 100 \\
\hline & 20. Genova & 0.010 & 0.126 & 0.843 & 0.015 & 0.005 & 0.000 & - & - & - & 99 \\
\hline & 21. Livorno & 0.005 & 0.096 & 0.874 & 0.025 & 0.000 & 0.000 & - & - & - & 99 \\
\hline \multirow[t]{20}{*}{ Lap-1 } & 1. Santander & 0.000 & 0.012 & 0.029 & 0.035 & 0.436 & 0.459 & 0.029 & 0.000 & - & 86 \\
\hline & 2. Ribadeo & 0.000 & 0.011 & 0.011 & 0.005 & 0.440 & 0.484 & 0.049 & 0.000 & - & 91 \\
\hline & 3. Malata & 0.000 & 0.006 & 0.040 & 0.023 & 0.449 & 0.438 & 0.045 & 0.000 & - & 88 \\
\hline & 4. Sada & 0.000 & 0.020 & 0.059 & 0.010 & 0.455 & 0.421 & 0.035 & 0.000 & - & 101 \\
\hline & 5. Laxe & 0.000 & 0.000 & 0.034 & 0.053 & 0.403 & 0.471 & 0.039 & 0.000 & - & 103 \\
\hline & 6. Portosin & 0.000 & 0.011 & 0.049 & 0.016 & 0.359 & 0.527 & 0.038 & 0.000 & - & 92 \\
\hline & 7. Carril & 0.000 & 0.010 & 0.029 & 0.025 & 0.436 & 0.495 & 0.005 & 0.000 & - & 102 \\
\hline & 8. Rande & 0.008 & 0.024 & 0.048 & 0.020 & 0.363 & 0.496 & 0.040 & 0.000 & - & 124 \\
\hline & 9. Silleiro & 0.000 & 0.000 & 0.033 & 0.000 & 0.375 & 0.571 & 0.022 & 0.000 & - & 92 \\
\hline & 10. Aveiro & 0.000 & 0.000 & 0.047 & 0.042 & 0.380 & 0.500 & 0.026 & 0.005 & - & 96 \\
\hline & 11. Sesimbra & 0.014 & 0.007 & 0.014 & 0.014 & 0.426 & 0.480 & 0.047 & 0.000 & - & 74 \\
\hline & 12. Marbella & 0.000 & 0.008 & 0.000 & 0.023 & 0.348 & 0.591 & 0.030 & 0.000 & - & 66 \\
\hline & 13. Almeria & 0.003 & 0.003 & 0.016 & 0.035 & 0.461 & 0.452 & 0.029 & 0.000 & - & 155 \\
\hline & 14. Alicante & 0.000 & 0.033 & 0.022 & 0.088 & 0.430 & 0.404 & 0.022 & 0.000 & - & 136 \\
\hline & 15. Cullera & 0.008 & 0.023 & 0.033 & 0.089 & 0.376 & 0.457 & 0.012 & 0.002 & - & 242 \\
\hline & 16. Garraf & 0.000 & 0.000 & 0.069 & 0.083 & 0.375 & 0.431 & 0.042 & 0.000 & - & 36 \\
\hline & 18. Palavas & 0.000 & 0.011 & 0.065 & 0.086 & 0.409 & 0.409 & 0.022 & 0.000 & - & 93 \\
\hline & 19. Montecarlo & 0.000 & 0.016 & 0.008 & 0.048 & 0.435 & 0.476 & 0.016 & 0.000 & - & 62 \\
\hline & 20. Genova & 0.000 & 0.021 & 0.016 & 0.094 & 0.406 & 0.427 & 0.036 & 0.000 & - & 96 \\
\hline & 21. Livorno & 0.000 & 0.029 & 0.058 & 0.064 & 0.355 & 0.453 & 0.029 & 0.012 & - & 86 \\
\hline \multirow[t]{13}{*}{ Lap-2 } & 1. Santander & 0.000 & 0.056 & 0.472 & 0.000 & 0.465 & 0.000 & 0.007 & 0.000 & 0.000 & 71 \\
\hline & 2. Ribadeo & 0.000 & 0.021 & 0.537 & 0.000 & 0.395 & 0.000 & 0.047 & 0.000 & 0.000 & 95 \\
\hline & 3. Malata & 0.005 & 0.036 & 0.536 & 0.010 & 0.388 & 0.000 & 0.026 & 0.000 & 0.000 & 98 \\
\hline & 6. Portosin & 0.010 & 0.040 & 0.510 & 0.000 & 0.414 & 0.000 & 0.025 & 0.000 & 0.000 & 99 \\
\hline & 8. Rande & 0.000 & 0.029 & 0.485 & 0.000 & 0.466 & 0.000 & 0.019 & 0.000 & 0.000 & 103 \\
\hline & 9. Silleiro & 0.000 & 0.016 & 0.521 & 0.000 & 0.432 & 0.000 & 0.031 & 0.000 & 0.000 & 96 \\
\hline & 10. Aveiro & 0.000 & 0.026 & 0.469 & 0.000 & 0.464 & 0.000 & 0.036 & 0.005 & 0.000 & 98 \\
\hline & 11. Sesimbra & 0.000 & 0.034 & 0.486 & 0.000 & 0.439 & 0.000 & 0.041 & 0.000 & 0.000 & 74 \\
\hline & 12. Marbella & 0.011 & 0.006 & 0.494 & 0.000 & 0.461 & 0.000 & 0.028 & 0.000 & 0.000 & 90 \\
\hline & 13. Almeria & 0.000 & 0.045 & 0.473 & 0.000 & 0.461 & 0.000 & 0.021 & 0.000 & 0.000 & 168 \\
\hline & 14. Alicante & 0.000 & 0.011 & 0.489 & 0.000 & 0.438 & 0.000 & 0.058 & 0.000 & 0.004 & 138 \\
\hline & 15. Cullera & 0.000 & 0.040 & 0.512 & 0.002 & 0.416 & 0.000 & 0.030 & 0.000 & 0.000 & 214 \\
\hline & 16. Garraf & 0.000 & 0.053 & 0.474 & 0.000 & 0.434 & 0.000 & 0.039 & 0.000 & 0.000 & 38 \\
\hline
\end{tabular}


Appendix (continued)

\begin{tabular}{|c|c|c|c|c|c|c|c|c|c|c|c|}
\hline Locus & Population & 1 & 2 & 3 & 4 & $\begin{array}{c}\text { Allele } \\
5\end{array}$ & 6 & 7 & 8 & 9 & $\mathrm{~N}$ \\
\hline Lap-2 & $\begin{array}{l}\text { 17. LLansa } \\
\text { 18. Palavas } \\
\text { 19. Montecarlo } \\
\text { 20. Genova } \\
\text { 21. Livorno }\end{array}$ & $\begin{array}{l}0.000 \\
0.005 \\
0.000 \\
0.000 \\
0.000\end{array}$ & $\begin{array}{l}0.010 \\
0.015 \\
0.025 \\
0.026 \\
0.044\end{array}$ & $\begin{array}{l}0.510 \\
0.465 \\
0.540 \\
0.442 \\
0.440\end{array}$ & $\begin{array}{l}0.000 \\
0.005 \\
0.000 \\
0.000 \\
0.000\end{array}$ & $\begin{array}{l}0.408 \\
0.425 \\
0.359 \\
0.447 \\
0.434\end{array}$ & $\begin{array}{l}0.000 \\
0.000 \\
0.000 \\
0.000 \\
0.000\end{array}$ & $\begin{array}{l}0.071 \\
0.085 \\
0.076 \\
0.084 \\
0.082\end{array}$ & $\begin{array}{l}0.000 \\
0.000 \\
0.000 \\
0.000 \\
0.000\end{array}$ & $\begin{array}{l}0.000 \\
0.000 \\
0.000 \\
0.000 \\
0.000\end{array}$ & $\begin{array}{r}98 \\
100 \\
99 \\
95 \\
91\end{array}$ \\
\hline Mpi & $\begin{array}{l}\text { 1. Santander } \\
\text { 2. Ribadeo } \\
\text { 3. Malata } \\
\text { 4. Sada } \\
\text { 5. Laxe } \\
\text { 6. Portosin } \\
\text { 7. Carril } \\
\text { 8. Rande } \\
\text { 9. Silleiro } \\
\text { 10. Aveiro } \\
\text { 11. Sesimbra } \\
\text { 12. Marbella } \\
\text { 13. Almeria } \\
\text { 14. Alicante } \\
\text { 15. Cullera } \\
\text { 16. Garraf } \\
\text { 17. LLansa } \\
\text { 18. Palavas } \\
\text { 19. Montecarlo } \\
\text { 20. Genova } \\
\text { 21. Livorno }\end{array}$ & $\begin{array}{l}0.005 \\
0.000 \\
0.000 \\
0.010 \\
0.000 \\
0.005 \\
0.022 \\
0.000 \\
0.000 \\
0.005 \\
0.020 \\
0.005 \\
0.008 \\
0.000 \\
0.000 \\
0.000 \\
0.000 \\
0.000 \\
0.005 \\
0.000 \\
0.005\end{array}$ & $\begin{array}{l}0.960 \\
0.954 \\
0.960 \\
0.933 \\
0.919 \\
0.973 \\
0.888 \\
0.937 \\
0.914 \\
0.955 \\
0.926 \\
0.978 \\
0.969 \\
0.960 \\
0.962 \\
1.000 \\
0.913 \\
0.967 \\
0.975 \\
0.969 \\
0.975\end{array}$ & $\begin{array}{l}0.035 \\
0.041 \\
0.040 \\
0.053 \\
0.081 \\
0.022 \\
0.084 \\
0.063 \\
0.081 \\
0.040 \\
0.054 \\
0.016 \\
0.023 \\
0.040 \\
0.038 \\
0.000 \\
0.087 \\
0.033 \\
0.020 \\
0.031 \\
0.020\end{array}$ & $\begin{array}{l}0.000 \\
0.005 \\
0.000 \\
0.005 \\
0.000 \\
0.000 \\
0.006 \\
0.000 \\
0.005 \\
0.000 \\
0.000 \\
0.000 \\
0.000 \\
0.000 \\
0.000 \\
0.000 \\
0.000 \\
0.000 \\
0.000 \\
0.000 \\
0.000\end{array}$ & $\begin{array}{l}- \\
- \\
- \\
- \\
- \\
- \\
- \\
- \\
- \\
- \\
- \\
- \\
- \\
- \\
-\end{array}$ & $\begin{array}{l}- \\
- \\
- \\
- \\
- \\
- \\
- \\
- \\
- \\
- \\
- \\
- \\
- \\
- \\
- \\
-\end{array}$ & $\begin{array}{l}- \\
- \\
- \\
- \\
- \\
- \\
- \\
- \\
- \\
- \\
- \\
- \\
- \\
- \\
- \\
- \\
- \\
-\end{array}$ & $\begin{array}{l}- \\
- \\
\overline{-} \\
- \\
- \\
- \\
- \\
- \\
- \\
- \\
- \\
- \\
- \\
- \\
- \\
-\end{array}$ & $\begin{array}{l}- \\
- \\
- \\
- \\
- \\
- \\
- \\
- \\
- \\
- \\
- \\
- \\
- \\
- \\
- \\
- \\
-\end{array}$ & $\begin{array}{r}100 \\
98 \\
87 \\
104 \\
105 \\
93 \\
89 \\
119 \\
99 \\
99 \\
74 \\
91 \\
131 \\
99 \\
173 \\
16 \\
52 \\
75 \\
100 \\
97 \\
99\end{array}$ \\
\hline Odh & $\begin{array}{l}\text { 1. Santander } \\
\text { 2. Ribadeo } \\
\text { 3. Malata } \\
\text { 4. Sada } \\
\text { 5. Laxe } \\
\text { 6. Portosin } \\
\text { 7. Carril } \\
\text { 8. Rande } \\
\text { 9. Silleiro } \\
\text { 10. Aveiro } \\
\text { 11. Sesimbra } \\
\text { 12. Marbella } \\
\text { 13. Almeria } \\
\text { 14. Alicante } \\
\text { 15. Cullera } \\
\text { 16. Garraf } \\
\text { 17. LLansa } \\
\text { 18. Palavas } \\
\text { 19. Montecarlo } \\
\text { 20. Genova } \\
\text { 21. Livorno }\end{array}$ & $\begin{array}{l}0.000 \\
0.005 \\
0.011 \\
0.020 \\
0.000 \\
0.015 \\
0.005 \\
0.012 \\
0.015 \\
0.000 \\
0.000 \\
0.000 \\
0.003 \\
0.000 \\
0.004 \\
0.000 \\
0.000 \\
0.005 \\
0.000 \\
0.000 \\
0.000\end{array}$ & $\begin{array}{l}0.000 \\
0.000 \\
0.000 \\
0.000 \\
0.000 \\
0.000 \\
0.000 \\
0.000 \\
0.000 \\
0.000 \\
0.000 \\
0.000 \\
0.000 \\
0.000 \\
0.000 \\
0.000 \\
0.000 \\
0.000 \\
0.000 \\
0.000 \\
0.000\end{array}$ & $\begin{array}{l}0.543 \\
0.500 \\
0.554 \\
0.574 \\
0.578 \\
0.525 \\
0.518 \\
0.544 \\
0.521 \\
0.551 \\
0.534 \\
0.655 \\
0.658 \\
0.107 \\
0.121 \\
0.205 \\
0.118 \\
0.136 \\
0.133 \\
0.143 \\
0.085\end{array}$ & $\begin{array}{l}0.000 \\
0.000 \\
0.000 \\
0.000 \\
0.005 \\
0.000 \\
0.000 \\
0.000 \\
0.000 \\
0.000 \\
0.000 \\
0.000 \\
0.000 \\
0.000 \\
0.000 \\
0.000 \\
0.000 \\
0.000 \\
0.000 \\
0.000 \\
0.000\end{array}$ & $\begin{array}{l}0.000 \\
0.005 \\
0.000 \\
0.004 \\
0.009 \\
0.000 \\
0.000 \\
0.004 \\
0.005 \\
0.005 \\
0.000 \\
0.000 \\
0.000 \\
0.000 \\
0.000 \\
0.011 \\
0.000 \\
0.000 \\
0.005 \\
0.000 \\
0.005\end{array}$ & $\begin{array}{l}0.140 \\
0.126 \\
0.151 \\
0.098 \\
0.128 \\
0.141 \\
0.191 \\
0.104 \\
0.160 \\
0.111 \\
0.144 \\
0.085 \\
0.091 \\
0.263 \\
0.193 \\
0.273 \\
0.274 \\
0.202 \\
0.173 \\
0.163 \\
0.185\end{array}$ & $\begin{array}{l}0.000 \\
0.000 \\
0.000 \\
0.008 \\
0.000 \\
0.000 \\
0.000 \\
0.000 \\
0.000 \\
0.000 \\
0.000 \\
0.000 \\
0.000 \\
0.000 \\
0.000 \\
0.000 \\
0.000 \\
0.000 \\
0.000 \\
0.005 \\
0.000\end{array}$ & $\begin{array}{l}0.317 \\
0.343 \\
0.258 \\
0.283 \\
0.280 \\
0.318 \\
0.264 \\
0.316 \\
0.294 \\
0.328 \\
0.322 \\
0.260 \\
0.246 \\
0.622 \\
0.675 \\
0.511 \\
0.602 \\
0.646 \\
0.679 \\
0.689 \\
0.715\end{array}$ & $\begin{array}{l}0.000 \\
0.020 \\
0.027 \\
0.012 \\
0.000 \\
0.000 \\
0.023 \\
0.020 \\
0.005 \\
0.005 \\
0.000 \\
0.000 \\
0.003 \\
0.008 \\
0.008 \\
0.000 \\
0.005 \\
0.010 \\
0.010 \\
0.000 \\
0.010\end{array}$ & $\begin{array}{r}93 \\
99 \\
93 \\
122 \\
109 \\
99 \\
110 \\
125 \\
97 \\
99 \\
73 \\
100 \\
171 \\
131 \\
257 \\
44 \\
93 \\
99 \\
98 \\
98 \\
100\end{array}$ \\
\hline $6 P g d h$ & $\begin{array}{l}\text { 1. Santander } \\
\text { 2. Ribadeo } \\
\text { 3. Malata } \\
\text { 4. Sada } \\
\text { 5. Laxe } \\
\text { 6. Portosin } \\
\text { 7. Carril } \\
\text { 8. Rande } \\
\text { 9. Silleiro } \\
\text { 10. Aveiro } \\
\text { 11. Sesimbra } \\
\text { 12. Marbella } \\
\text { 13. Almeria } \\
\text { 14. Alicante } \\
\text { 15. Cullera } \\
\text { 16. Garraf } \\
\text { 17. LLansa } \\
\text { 18. Palavas } \\
\text { 19. Montecarlo } \\
\text { 20. Genova } \\
\text { 21. Livorno }\end{array}$ & $\begin{array}{l}0.000 \\
0.005 \\
0.005 \\
0.009 \\
0.005 \\
0.005 \\
0.005 \\
0.000 \\
0.005 \\
0.000 \\
0.000 \\
0.011 \\
0.003 \\
0.000 \\
0.000 \\
0.000 \\
0.000 \\
0.005 \\
0.000 \\
0.000 \\
0.000\end{array}$ & $\begin{array}{l}0.032 \\
0.015 \\
0.037 \\
0.046 \\
0.055 \\
0.040 \\
0.053 \\
0.035 \\
0.020 \\
0.015 \\
0.047 \\
0.032 \\
0.016 \\
0.011 \\
0.019 \\
0.013 \\
0.010 \\
0.021 \\
0.013 \\
0.020 \\
0.020\end{array}$ & $\begin{array}{l}0.011 \\
0.000 \\
0.011 \\
0.009 \\
0.000 \\
0.005 \\
0.011 \\
0.012 \\
0.000 \\
0.010 \\
0.027 \\
0.005 \\
0.000 \\
0.000 \\
0.011 \\
0.000 \\
0.000 \\
0.000 \\
0.000 \\
0.005 \\
0.020\end{array}$ & $\begin{array}{l}0.926 \\
0.974 \\
0.937 \\
0.921 \\
0.912 \\
0.930 \\
0.905 \\
0.921 \\
0.940 \\
0.933 \\
0.892 \\
0.910 \\
0.934 \\
0.974 \\
0.948 \\
0.950 \\
0.969 \\
0.964 \\
0.953 \\
0.945 \\
0.944\end{array}$ & $\begin{array}{l}0.005 \\
0.000 \\
0.005 \\
0.000 \\
0.005 \\
0.010 \\
0.016 \\
0.000 \\
0.000 \\
0.010 \\
0.000 \\
0.000 \\
0.003 \\
0.004 \\
0.000 \\
0.000 \\
0.010 \\
0.000 \\
0.000 \\
0.005 \\
0.000\end{array}$ & $\begin{array}{l}0.026 \\
0.005 \\
0.000 \\
0.014 \\
0.022 \\
0.010 \\
0.011 \\
0.028 \\
0.035 \\
0.031 \\
0.034 \\
0.043 \\
0.044 \\
0.011 \\
0.019 \\
0.025 \\
0.010 \\
0.010 \\
0.033 \\
0.020 \\
0.015\end{array}$ & $\begin{array}{l}0.000 \\
0.000 \\
0.005 \\
0.000 \\
0.000 \\
0.000 \\
0.000 \\
0.004 \\
0.000 \\
0.000 \\
0.000 \\
0.000 \\
0.000 \\
0.000 \\
0.000 \\
0.013 \\
0.000 \\
0.000 \\
0.000 \\
0.005 \\
0.000\end{array}$ & $\begin{array}{l}0.000 \\
0.000 \\
0.000 \\
0.000 \\
0.000 \\
0.000 \\
0.000 \\
0.000 \\
0.000 \\
0.000 \\
0.000 \\
0.000 \\
0.000 \\
0.000 \\
0.004 \\
0.000 \\
0.000 \\
0.000 \\
0.000 \\
0.000 \\
0.000\end{array}$ & $\begin{array}{l}- \\
- \\
- \\
- \\
- \\
- \\
- \\
- \\
- \\
- \\
- \\
- \\
- \\
- \\
- \\
- \\
- \\
- \\
- \\
-\end{array}$ & $\begin{array}{r}95 \\
97 \\
95 \\
108 \\
91 \\
100 \\
95 \\
127 \\
100 \\
97 \\
74 \\
94 \\
160 \\
135 \\
134 \\
40 \\
98 \\
97 \\
75 \\
100 \\
99\end{array}$ \\
\hline
\end{tabular}


Appendix (continued)

\begin{tabular}{|c|c|c|c|c|c|c|c|c|c|c|c|}
\hline Locus & Population & 1 & 2 & 3 & 4 & $\begin{array}{c}\text { Allele } \\
5\end{array}$ & 6 & 7 & 8 & 9 & $\mathrm{~N}$ \\
\hline \multirow[t]{18}{*}{$P g i$} & 1. Santander & 0.021 & 0.021 & 0.080 & 0.447 & 0.032 & 0.309 & 0.074 & 0.011 & 0.005 & 94 \\
\hline & 2. Ribadeo & 0.000 & 0.053 & 0.053 & 0.580 & 0.005 & 0.239 & 0.064 & 0.005 & 0.000 & 94 \\
\hline & 3. Malata & 0.006 & 0.029 & 0.052 & 0.592 & 0.000 & 0.241 & 0.046 & 0.034 & 0.000 & 87 \\
\hline & 6. Portosin & 0.000 & 0.006 & 0.040 & 0.551 & 0.011 & 0.301 & 0.063 & 0.028 & 0.000 & 88 \\
\hline & 8. Rande & 0.009 & 0.000 & 0.061 & 0.670 & 0.004 & 0.200 & 0.026 & 0.026 & 0.004 & 115 \\
\hline & 9. Silleiro & 0.000 & 0.016 & 0.089 & 0.516 & 0.011 & 0.247 & 0.068 & 0.053 & 0.000 & 95 \\
\hline & 10. Aveiro & 0.000 & 0.021 & 0.074 & 0.547 & 0.021 & 0.253 & 0.063 & 0.021 & 0.000 & 95 \\
\hline & 11. Sesimbra & 0.000 & 0.014 & 0.048 & 0.616 & 0.014 & 0.233 & 0.075 & 0.000 & 0.000 & 73 \\
\hline & 12. Marbella & 0.006 & 0.017 & 0.074 & 0.540 & 0.006 & 0.284 & 0.063 & 0.011 & 0.000 & 88 \\
\hline & 13. Almeria & 0.007 & 0.033 & 0.059 & 0.526 & 0.016 & 0.239 & 0.108 & 0.007 & 0.007 & 153 \\
\hline & 14. Alicante & 0.000 & 0.013 & 0.013 & 0.787 & 0.000 & 0.148 & 0.039 & 0.000 & 0.000 & 115 \\
\hline & 15. Cullera & 0.002 & 0.005 & 0.027 & 0.745 & 0.002 & 0.167 & 0.045 & 0.005 & 0.002 & 276 \\
\hline & 16. Garraf & 0.000 & 0.000 & 0.035 & 0.779 & 0.000 & 0.163 & 0.023 & 0.000 & 0.000 & 43 \\
\hline & 17. LLansa & 0.000 & 0.010 & 0.046 & 0.784 & 0.005 & 0.124 & 0.026 & 0.005 & 0.000 & 97 \\
\hline & 18. Palavas & 0.000 & 0.011 & 0.037 & 0.777 & 0.000 & 0.160 & 0.016 & 0.000 & 0.000 & 94 \\
\hline & 19. Montecarlo & 0.000 & 0.000 & 0.023 & 0.753 & 0.000 & 0.201 & 0.011 & 0.011 & 0.000 & 87 \\
\hline & 20. Genova & 0.000 & 0.005 & 0.036 & 0.835 & 0.005 & 0.098 & 0.021 & 0.000 & 0.000 & 97 \\
\hline & 21. Livorno & 0.000 & 0.000 & 0.026 & 0.844 & 0.006 & 0.104 & 0.019 & 0.000 & 0.000 & 77 \\
\hline \multirow[t]{21}{*}{ Pgm } & 1. Santander & 0.000 & 0.017 & 0.099 & 0.570 & 0.000 & 0.297 & 0.017 & 0.000 & 0.000 & 86 \\
\hline & 2. Ribadeo & 0.005 & 0.011 & 0.113 & 0.640 & 0.000 & 0.215 & 0.000 & 0.016 & 0.000 & 93 \\
\hline & 3. Malata & 0.000 & 0.010 & 0.136 & 0.611 & 0.000 & 0.207 & 0.030 & 0.005 & 0.000 & 99 \\
\hline & 4. Sada & 0.000 & 0.013 & 0.087 & 0.675 & 0.000 & 0.200 & 0.013 & 0.013 & 0.000 & 40 \\
\hline & 5. Laxe & 0.000 & 0.027 & 0.095 & 0.541 & 0.007 & 0.324 & 0.000 & 0.007 & 0.000 & 74 \\
\hline & 6. Portosin & 0.000 & 0.006 & 0.145 & 0.599 & 0.000 & 0.227 & 0.012 & 0.012 & 0.000 & 86 \\
\hline & 7. Carril & 0.000 & 0.032 & 0.112 & 0.532 & 0.005 & 0.293 & 0.011 & 0.016 & 0.000 & 94 \\
\hline & 8. Rande & 0.000 & 0.029 & 0.131 & 0.561 & 0.000 & 0.270 & 0.008 & 0.000 & 0.000 & 122 \\
\hline & 9. Silleiro & 0.000 & 0.000 & 0.106 & 0.591 & 0.005 & 0.283 & 0.015 & 0.000 & 0.000 & 99 \\
\hline & 10. Aveiro & 0.000 & 0.005 & 0.069 & 0.633 & 0.000 & 0.271 & 0.016 & 0.000 & 0.005 & 94 \\
\hline & 11. Sesimbra & 0.014 & 0.000 & 0.103 & 0.630 & 0.000 & 0.253 & 0.000 & 0.000 & 0.000 & 73 \\
\hline & 12. Marbella & 0.000 & 0.015 & 0.103 & 0.619 & 0.000 & 0.253 & 0.010 & 0.000 & 0.000 & 97 \\
\hline & 13. Almeria & 0.003 & 0.012 & 0.104 & 0.610 & 0.006 & 0.251 & 0.012 & 0.003 & 0.000 & 173 \\
\hline & 14. Alicante & 0.020 & 0.036 & 0.133 & 0.515 & 0.000 & 0.276 & 0.010 & 0.010 & 0.000 & 98 \\
\hline & 15. Cullera & 0.002 & 0.030 & 0.125 & 0.513 & 0.000 & 0.302 & 0.019 & 0.009 & 0.000 & 268 \\
\hline & 16. Garraf & 0.000 & 0.054 & 0.135 & 0.568 & 0.000 & 0.243 & 0.000 & 0.000 & 0.000 & 37 \\
\hline & 17. LLansa & 0.000 & 0.036 & 0.134 & 0.500 & 0.000 & 0.304 & 0.021 & 0.005 & 0.000 & 97 \\
\hline & 18. Palavas & 0.010 & 0.036 & 0.120 & 0.573 & 0.000 & 0.255 & 0.000 & 0.005 & 0.000 & 96 \\
\hline & 19. Montecarlo & 0.020 & 0.040 & 0.162 & 0.475 & 0.000 & 0.293 & 0.010 & 0.000 & 0.000 & 99 \\
\hline & 20. Genova & 0.005 & 0.035 & 0.141 & 0.495 & 0.000 & 0.313 & 0.000 & 0.010 & 0.000 & 99 \\
\hline & 21. Livorno & 0.010 & 0.031 & 0.120 & 0.542 & 0.000 & 0.271 & 0.016 & 0.010 & 0.000 & 96 \\
\hline \multirow[t]{21}{*}{ Sod } & 1. Santander & 1.000 & - & - & - & - & - & - & - & - & 60 \\
\hline & 2. Ribadeo & 1.000 & - & - & - & - & - & - & - & - & 98 \\
\hline & 3. Malata & 1.000 & - & - & - & - & - & - & - & - & 80 \\
\hline & 4. Sada & 1.000 & - & - & - & - & - & - & - & - & 100 \\
\hline & 5. Laxe & 1.000 & - & - & - & - & - & - & - & - & 110 \\
\hline & 6. Portosin & 1.000 & - & - & - & - & - & - & - & - & 99 \\
\hline & 7. Carril & 1.000 & - & - & - & - & - & - & - & - & 80 \\
\hline & 8. Rande & 1.000 & - & - & - & - & - & - & - & - & 122 \\
\hline & 9. Silleiro & 1.000 & - & - & - & - & - & - & - & - & 96 \\
\hline & 10. Aveiro & 1.000 & - & - & - & - & - & - & - & - & 40 \\
\hline & 11. Sesimbra & 1.000 & - & - & - & - & - & - & - & - & 38 \\
\hline & 12. Marbella & 1.000 & - & - & - & - & - & - & - & - & 40 \\
\hline & 13. Almeria & 1.000 & - & - & - & - & - & - & - & - & 118 \\
\hline & 14. Alicante & 1.000 & - & - & - & - & - & - & - & - & 139 \\
\hline & 15. Cullera & 1.000 & - & - & - & - & - & - & - & - & 240 \\
\hline & 16. Garraf & 1.000 & - & - & - & - & - & - & - & - & 46 \\
\hline & 17. LLansa & 1.000 & - & - & - & - & - & - & - & - & 60 \\
\hline & 18. Palavas & 1.000 & - & - & - & - & - & - & - & - & 40 \\
\hline & 19. Montecarlo & 1.000 & - & - & - & - & - & - & - & - & 40 \\
\hline & 20. Genova & 1.000 & - & - & - & - & - & - & - & - & 40 \\
\hline & 21. Livorno & 1.000 & - & - & - & - & - & - & - & - & 40 \\
\hline \multirow[t]{8}{*}{ Stdh } & 1. Santander & 0.000 & 0.148 & 0.000 & 0.112 & 0.010 & 0.061 & 0.653 & 0.005 & 0.010 & 98 \\
\hline & 2. Ribadeo & 0.011 & 0.068 & 0.023 & 0.051 & 0.034 & 0.102 & 0.676 & 0.017 & 0.017 & 88 \\
\hline & 3. Malata & 0.000 & 0.118 & 0.000 & 0.139 & 0.028 & 0.097 & 0.576 & 0.028 & 0.014 & 72 \\
\hline & 6. Portosin & 0.000 & 0.124 & 0.011 & 0.124 & 0.027 & 0.065 & 0.624 & 0.022 & 0.005 & 93 \\
\hline & 8. Rande & 0.013 & 0.143 & 0.004 & 0.087 & 0.035 & 0.091 & 0.565 & 0.057 & 0.004 & 115 \\
\hline & 9. Silleiro & 0.011 & 0.079 & 0.000 & 0.084 & 0.021 & 0.089 & 0.689 & 0.016 & 0.011 & 95 \\
\hline & 10. Aveiro & 0.006 & 0.120 & 0.000 & 0.114 & 0.006 & 0.072 & 0.669 & 0.012 & 0.000 & 83 \\
\hline & 12. Marbella & 0.011 & 0.126 & 0.000 & 0.144 & 0.052 & 0.080 & 0.557 & 0.029 & 0.000 & 87 \\
\hline
\end{tabular}


Appendix (continued)

\begin{tabular}{|c|c|c|c|c|c|c|c|c|c|c|c|}
\hline Locus & Population & 1 & 2 & 3 & 4 & $\begin{array}{c}\text { Allele } \\
5\end{array}$ & 6 & 7 & 8 & 9 & $\mathrm{~N}$ \\
\hline \multirow[t]{9}{*}{ Stdh } & 13. Almería & 0.000 & 0.114 & 0.000 & 0.182 & 0.023 & 0.068 & 0.602 & 0.000 & 0.011 & 44 \\
\hline & 14. Alicante & 0.000 & 0.163 & 0.000 & 0.144 & 0.000 & 0.048 & 0.644 & 0.000 & 0.000 & 52 \\
\hline & 15. Cullera & 0.000 & 0.157 & 0.000 & 0.100 & 0.014 & 0.000 & 0.700 & 0.029 & 0.000 & 35 \\
\hline & 16. Garraf & 0.000 & 0.175 & 0.000 & 0.175 & 0.000 & 0.000 & 0.637 & 0.000 & 0.013 & 40 \\
\hline & 17. LLansa & 0.000 & 0.131 & 0.000 & 0.142 & 0.023 & 0.000 & 0.670 & 0.011 & 0.023 & 88 \\
\hline & 18. Palavas & 0.005 & 0.199 & 0.000 & 0.051 & 0.000 & 0.031 & 0.694 & 0.020 & 0.000 & 98 \\
\hline & 19. Montecarlo & 0.005 & 0.227 & 0.010 & 0.101 & 0.005 & 0.005 & 0.636 & 0.010 & 0.000 & 99 \\
\hline & 20. Genova & 0.005 & 0.232 & 0.000 & 0.137 & 0.016 & 0.021 & 0.584 & 0.005 & 0.000 & 95 \\
\hline & 21. Livorno & 0.005 & 0.184 & 0.000 & 0.071 & 0.000 & 0.005 & 0.714 & 0.010 & 0.010 & 98 \\
\hline
\end{tabular}

Acknowledgements. We thank A. Quesada and F. Rodriguez for their encouragement and help in collecting samples, and M. Reyero for technical assistance. We are also grateful to E. Rolan-Alvarez and C. Saavedra for helpful discussions, and D. O. F. Skibinski for valuable comments and criticisms of an earlier draft of the manuscript. One of us (H.Q.) was supported by a F.P.I. fellowship from the Ministerio de Educacion y Ciencia.

\section{LITERATURE CITED}

Ahmad, M., Skibinski, D. O. F., Beardmore, J. A. (1977). An estimate of the amount of genetic variation in the common mussel Mytilus edulis. Biochem. Genet. 15: 833-846

Amores, A., Giles, V., Thode, G., Alvarez, M. C. (1990). Adaptative character of a Robertsonian fusion in chromosomes of the fish Gobious paganellus (Pisces, Pesciformes). Heredity 65: 151-155

Arnone, R. A., La Violette, P. E. (1986). Satellite definition of the bio-optical and thermal variation of coastal eddies associated with the African current. J. geophys. Res. 91: 2351-2364

Arnone, R. A., Wiesenburg, D. A., Saunders, K. D. (1990). The origin and characteristics of the Algerian current. J. geophys. Res. 95: 1587-1598

Avise, J. C. (1992). Molecular population structure and the biogeographic history of a regional fauna: a case history with lessons for conservation biology. Oikos 63: 62-76

Avise, J. C., Arnold, J., Ball, R. M., Bermingham, E., Lamb, T., Neigel, J. E., Reeb, C. A., Saunders, N. C. (1987). Intraspecific phylogeography: the mitochondrial DNA bridge between population genetics and systematics. A. Rev. Ecol. Syst. 18: 489-522

Ayvazian, S. G., Johnson, M. S., McGlashan, D. J. (1994). High levels of genetic subdivision of marine and estuarine populations of the estuarine catfish Cnidoglanis macrocephalus (Plotosidae) in southwestern Australia. Mar. Biol. 118: 25-31

Barton, N. H. (1979). Gene flow past a cline. Heredity 43: 333-339

Barton, N. H. (1982). The structure of the hybrid zone in Uroderma bilobatum (Chiroptera: Phyllotomatidae). Evolution 36: $863-866$

Barton, N. H., Hewitt, G. M. (1985). Analysis of hybrid zones. A. Rev. Ecol. Syst. 16: 113-148

Barton, N. H., Hewitt, G. M. (1989). Adaptation, speciation and hybrid zones. Nature 341: 497-503

Bayne, B. L. (1965). Growth and the delay of metamorphosis of the larvae of Mytilus edulis (L.). Ophelia 2: 4-47
Bayne, B. L. (1976). The biology of mussel larvae. In: Bayne, B. L. (ed.) Marine mussels: their ecology and physiology. Cambridge University Press, Cambridge, p. 81-120

Beaumont, A. R. (1982). Geographic variation in allele frequencies at three loci in Chlamis opercularis from the Norway to the Brittany coast. J. mar. biol. Ass. U.K. 62: 243-261

Bert, T. M., Harrison, R. G. (1988). Hybridization in western Atlantic stone crabs (Genus Menippe): evolutionary history and ecological context influence species interactions. Evolution 42: 528-544

Bertness, M. D., Gaines, S. D. (1993). Larval dispersal and local adaptation in acorn barnacles. Evolution 47(1): $316-320$

Bulnheim, H. P., Scholl, A. (1981). Genetic variation between geographic populations of the amphipods Gammarus zaddachi and G. salinus. Mar. Biol. 64: 105-115

Buroker, N. E. (1983). Population genetics of the American oyster Crassostrea virginica along the Atlantic coasts and the Gulf of Mexico. Mar. Biol. 75: 99-112

Burton, R. S. (1983). Protein polymorphisms and genetic differentiation of marine invertebrate populations. Mar. Biol. Lett. 4: 193-206

Burton, R. S., Feldman, M. W. (1982). Population genetics of coastal and estuarine invertebrates: does larval behavior influence population structure?. In: Kennedy, V. S. (ed.) Estuarine comparisons. Academic Press, New York, p. $537-551$

Capel, J. J. (1981). Los climas de Espana. Oikos-Tav Ediciones, Barcelona

Chakraborty, R. (1980). Gene-diversity analysis in nested subdivided populations. Genetics 96: 721-723

Christiansen, F. B., Frydenberg, O. (1974). Geographical patterns of four polymorphisms in Zoarces viviparus as evidence of selection. Genetics 77: 765-770

Collier, A. W. (1970). Oceans and coastal waters as life supporting environments. In: Kinne, O. (ed.) Marine ecology, Vol 1, Part 1, Environmental factors. Wiley-Interscience, London, p. 1-94

Conde, F., Seoane, J. A. (1982). Corologia de las especies de algas en relacion a ciertos factores ecológicos en el litoral malagueño. Collect. Bot. 13: 783-802

Dando, P. R., Southward, A. J. (1981). Existence of 'Atlantic' and 'Mediterranean' forms of Chthamalus montagui (Crustacea, cirripedia) in the Western Mediterranean. Mar. Biol. Lett. 2: 239-248

Dando, P. R., Storey, K. B., Hochachka, P. W., Storey, J. M. (1981). Multiple dehydrogenases in marine molluscs: electrophoretic analysis of alanopine dehydrogenase, strombine dehydrogenase, octopine dehydrogenase and lactate 
dehydrogenase. Mar. Biol. Lett. 2: 249-257

Davis, B. J., DeMartini, E. E., McGee, K. (1981). Gene flow among populations of a teleost (painted greenling, Oxylebius pictus) from Puget Sound to southern California. Mar. Biol. 65: 17-23

Endler, J. A. (1977). Geographic variation, clines, and speciation. Princeton Univ. Press, Princeton, NJ

Ferguson, A. (1980). Biochemical systematics and evolution. Blackie, Glasgow

Fujio, Y. (1979). Enzyme polymorphism and population structure of the Pacific oyster, Crassostrea gigas. Tohoku J. agr. Res. 30: 32-42

Fujio, Y., Yamanaka, R., Smith, P. J. (1983). Genetic variation in marine molluscs. Bull. Jap. Soc. scient. Fish. 49: 1809-1817

Garcia-Raso, J. E., Luque, A. A., Templado, J., Salas, C., Hergueta, E., Moreno, D., Calvo, M. (1992). Fauna y flora marinas del parque natural de Cabo de Gata-Nijar. Museo de Ciencias Naturales, Madrid

Gardner, J. P. A. (1992). Mytilus galloprovincialis (Lmk.) (Bivalvia, Mollusca): the taxonomic status of the mediterranean mussel. Ophelia 35(3): 219-243

Gosling, E. M. (1992a). The mussel Mytilus: ecology, physiology, genetics and culture. Elsevier, Amsterdam

Gosling, E. M. (1992b). Systematics and geographical distribution of Mytilus. In: Gosling, E. M. (ed.) The mussel Mytilus: ecology, physiology, genetics and culture. Elsevier, Amsterdam, p. 1-20

Gosling, E. M. (1992c). Genetics of Mytilus. In: Gosling, E. M. (ed.) The mussel Mytilus: ecology, physiology, genetics and culture. Elsevier, Amsterdam, p. 309-382

Grant, W. S., Cherry, M. I. (1985). Mytilus galloprovincialis Lmk. in southern Africa, J. exp. mar. Biol. Ecol. 90: 179-191

Haberman, S. J. (1988). A warning on the use of chi-squared statistics with frequency tables with small expected cell counts. J, Am. Ass. 83: 555-560

Harris, H., Hopkinson, D. A. (1976). Handbook of enzyme electrophoresis in human genetics. American Elsevier, New York

Hedgecock, R. (1986). Is gene flow from pelagic larval dispersal important in the adaptation and evolution of marine invertebrates?. Bull. mar. Sci. 39: 550-565

Hewitt, G. M. (1989). The subdivision of species by hybrid zones. In: Otte, D., Endler, J. A. (eds.) Speciation and its consequences. Sinauer, Sunderland, MA, p. 85-110

Holm, S. (1979). A simple sequentially rejective multiple test procedure. Scand. J. Stat. 6: 65-70

Hvilson, M. M., Theisen, B. F. (1984). Inheritance of allozyme variants through crossing experiments with the mussel Mytilus edulis L. Hereditas 101: 1-7

Johnson, M. S. (1974). Comparative geographic variation in Menidia. Evolution 28: 607-618

Koehn, R. K. (1991). The genetics and taxonomy of species in the genus Mytilus. Aquaculture 94: 125-145

Koehn, R. K., Hilbish, T. H. (1987). The adaptative importance of genetic variation. Am. Scient. 5: 134-141

Koehn, R. K., Milkman, R., Mitton, J. (1976). Population genetics of marine pelecypods. IV. Selection, migration and genetic differentiation in the blue mussel Mytilus edulis. Evolution 30: 2-32

Levinton, J. S., Suchanek, T. H. (1978). Geographic variation, niche breath and genetic differentiation at different geographic scales in the mussels Mytilus edulis and Mytilus californianus. Mar. Biol. 49: 363-375

Lohrenz, S. E., Wiesenburg, D. A., DePalma, I. P., Johnson, K. S., Gustafson, D. E. (1988). Interrelationship among pri- mary production, chlorophyll, and environmental conditions in frontal regions of the western Mediterranean sea. Deep Sea Res. 35: 793-810

Loubere, P. (1982). The western Mediterranean during the last glacial: attacking a no-analog problem. Mar. Micropaleont. 7: 311-325

Love, M. S., Larson, R. J. (1978). Geographic variation in the occurrence of tympanic spines and possible genetic differentiation in the kelp rockfish (Sebastes atrovirens). Copeia 1978: $53-59$

Lutz, R. A., Kennish, M. J. (1992). Ecology and morphology of larval and early postlarval mussels. In: Gosling, E. M. (ed.) The mussel Mytilus: ecology, physiology, genetics and culture. Elsevier, Amsterdam, p. 53-85

Macaranas, M., Ablan, C. A., Pante, M. J. R., Benzie, J. A. H., Williams, S. T. (1992). Genetic structure of giant clam (Tridacna derasa) populations from reefs in the Indo-Pacific. Mar. Biol. 113: 231-238

Marcus, N. C. (1977). Genetic variation within and between geographically separated populations of the sea urchin, Arbacia punctulata. Biol. Bull. 153: 560-576

Miller, R. G. (1981). Simultaneous statistical inference. McGraw Hill, New York

Milton, J. B., Berg, C. J., Orr, K. S. (1989). Population structure, larval dispersal and gene flow in the queen conch, Strombus gigas, of the Caribbean. Biol. Bull. 177: 356-362

Mork, J., Ryman, N., Stahl, G., Utter, F. (1985). Genetic variation in Atlantic Cod (Gadus morhua) throughout its range. Can. J. Fish. Aquat. Sci. 42: 1580-1587

Nei, M. (1972). Genetic distance between populations. Am. Nat. 106: 283-292

Nei, M. (1973). Analysis of gene diversity in subdivided populations. Proc. natl Acad. Sci. U.S.A. 70: 3321-3323

Nei, M. (1987). Molecular evolutionay genetics. Columbia University Press, New York

Nei, A. H., Hull, C. H., Jenkins, J. G., Steinbrenner, K., Bent, D. H. (1970). SPSS statistical packcage for the social sciences, 2nd edn. McGraw-Hill, New York

Peres, J. M. (1989). Historia de la biota mediterránea y la colonización de las profundidades. In: Margalef, R. (ed.) El Mediterraneo Occidental. Omega, Barcelona, p. 200-234

Pesch, G. (1974). Protein polymorphisms in the hard clams Mercenaria mercenaria and Mercenaria campecheiensis. Biol. Bull. 146: 393-403

Pielou, E. C. (1979). Biogeography. John Wiley \& Sons, Inc., London

Planes, S. (1993). Genetic differentiation in relation to restricted larval dispersal of the convict surgeonfish Acanthurus triostegus in French Polynesia. Mar. Ecol. Prog. Ser. 98: $237-246$

Quesada, H. (1992). Estructura genetica de poblaciones naturales del mejillón Mytilus galloprovincialis Lmk. Tesis doctoral, Univ. Santiago de Compostela

Quesada, H., Sanjuan, J., Sanjuan, A. (1992). GENET2: a BASIC program for the analysis of deviations from HardyWeinberg law. J. Hered. 83: 460-461

Rice, W. R. (1989). Analyzing tables of statistical tests. Evolution 43: 223-225

Robertson, A., Hill, W. G. (1984). Deviations from HardyWeinberg proportions: sampling variances and use in estimation of inbreeding coefficients. Genetics 107: 703-718

Rodriguez, J. (1982). Oceanografia del Mar Mediterraneo. Piramide, Madrid

Rodriguez, J., Garcia, A., Rodriguez, V. (1979). Zooplanktonic communities of the divergence zone in the northwestern Alboran Sea. Mar. Ecol. 3: 133-142

Ropson, I. J., Brown, D. C., Powers, D. A. (1990). Biochemical 
genetics of Fundulus heteroclitus (L.). VI. Geographical variation in the gene frequencies of 15 loci. Evolution 44: $16-26$

Saavedra, C., Zapata, C., Guerra, A., Alvarez, G. (1993). Allozyme variation in European populations of the oyster Ostrea edulis. Mar. Biol. 115: 85-95

Sanjuan, A., Quesada, H., Zapata, C., Alvarez, G. (1990). On the occurrence of Mytilus galloprovincialis Lmk. on the N.W. coast of the Iberian Peninsula. J. exp. mar. Biol. Ecol. 143: $1-14$

Sarver, S. K., Foltz, D. W. (1993). Genetic population structure of a species' complex of blue mussels (Mytilus spp.). Mar. Biol. 117: 105-112

Sassaman, C., Yoshiyama, R. M. (1979). Lactate dehydrogenase: a polymorphism of Anoplarchus purpurescens. J. Hered. 70: 329-334

Schopf, T. J., Gooch, J. L. (1971). Gene frequencies in a marine ectoproct: a cline in natural populations related to sea temperature. Evolution 25: 286-289

Schopf, T. J., Murphy, L. S. (1973). Protein polymorphism of the hybridizing seastar Asterias forbesi and Asterias vulgaris and implications for their evolution. Biol. Bull. 145: 589-597

Seed, R. (1992). Systematic evolution and distribution of mussels belonging to the genus Mytilus: an overview. Am. Malacol. Bull. 9: 123-137

Seed, R., Suchanek, T. H. (1992). Population and community ecology of Mytilus. In: Gosling, E. M. (ed.), The mussel Mytilus: ecology, physiology, genetics and culture. Elsevier, Amsterdam, p. 87-169

Shaw, C. R., Prasad, R. (1970). Starch gel electrophoresis of enzymes: a compilation of recipes. Biochem. Genet. 4: 297-320

Skibinski, D. O. F., Ahmad, M., Beardmore, J. A. (1978). Genetic evidence for naturally occurring hybrids between Mytilus edulis and Mytilus galloprovincialis. Evolution 32: 354-364

Skibinski, D. O. F., Beardmore, J. A., Cross, T. F. (1983). Aspects of the population genetics of Mytilus (Mytilidae: Mollusca) in the British Isles. Biol. J. Linn. Soc. 19: 137-183

Skibinski, D. O. F., Cross, T. D., Ahmad, M. (1980). Electrophoretic investigation of systematic relationship in the marine mussel Modiolus modiolus L., Mytilus edulis L., and Mytilus galloprovincilais Lmk (Mytilidae; Mollusca). Biol. J. Linn. Soc. 13: 65-73

Slatkin, M. (1985a). Rare alleles as indicators of gene flow. Evolution 39: 53-65

Slatkin, M. (1985b). Gene flow in natural populations. A. Rev. Ecol. Syst. 16: 393-430

This article was submitted to the editor
Slatkin, M., Barton, N. H. (1989). A comparison of three indirect methods for estimating average levels of gene flow. Evolution 43: 1343-1368

Sneath, P. H. A., Sokal, R. R. (1973). Numerical taxonomy. W. H. Freeman \& Co., San Francisco

Sokal, R. R, Rohlf, F. J. (1981). Biometry. W. H. Freeman \& Co., San Francisco

Solignac, M. (1976). Demographic aspects of interspecific hybridization. A study of the Jaera albifrons species complex (Crustacea, Isopoda, Asellota). Oecologia 26: 33-52

Swofford, D. L., Selander, R. K. (1981). BIOSYS-1: a FORTRAN program for the comprehensive analysis of electrophoretic data in population genetics and systematics. J. Hered. 72: 281-283

Thiede, J. (1978). A glacial Mediterranean. Nature 276: 680-683

Thunell, R. C. (1979). Pliocene-Pleistocene paleotemperature and paleosalinity history of the Mediterranean sea: results from DSDP sites 125 and 132. Mar. Micropaleont. 4: 173-187

Tintore, J., La Violette, P. E., Blade, I., Cruzado, A. (1988). A study of an intense density front in the eastern Alboran sea: the Almeria-Oran front. J. phys. Oceanogr. 18: 1384-1397

Tracey, M. L., Nelson, K., Hedgecock, D., Shleser, R. A., Pressick, M. L. (1975). Biochemical genetics of lobsters: genetic variation and the structure of American lobster (Homarus americanus) populations. J. Fish. Res. Bd Can. 32: $2091-2101$

Tsuchiya, M. (1983). Mass mortality in a population of the mussel Mytilus edulis L. caused by high temperature on rocky shores. J. exp. mar. Biol. Ecol. 66: 101-111

Väinölä, R., Hvilson, M. M. (1991). Genetic divergence and hybrid zone between Baltic and North Sea Mytilus populations (Mytilidae; Mollusca). Biol. J. Linn. Soc. 43: $127-148$

Väinölä, R., Varvio, S. L. (1989). Biosystematics of Macoma balthica in northwestern Europe. In: Ryland, J. S., Tyler, P. A. (eds.) Reproduction, genetics and distributions of marine organisms. Olsen and Olsen, Fredensborg, p. $309-316$

Varvio, S. L., Koehn, R. K., Väinölä, R. (1988). Evolutionary genetics of the Mytilus edulis complex in the North Atlantic region. Mar. Biol. 98: 51-60

Williams, G. C., Koehn, R. K., Mitton, J. B. (1973). Genetic differentiation without isolation in the American eel, Anguilla rostrata. Evolution 27: 192-204

Winans, G. A. (1980). Geographic variation in the milkfish Chanos chanos. I. Biochemical evidence. Evolution 34: $558-574$

Manuscript first received: May 19, 1994

Revised version accepted: September 26, 1994 